medRxiv preprint doi: https://doi.org/10.1101/2021.07.21.21260712; this version posted July 23, 2021. The copyright holder for this preprint (which was not certified by peer review) is the author/funder, who has granted medRxiv a license to display the preprint in perpetuity.

All rights reserved. No reuse allowed without permission.

\title{
Sex-specific effects of aging on the humoral immune response to repeat vaccination with the high-dose seasonal influenza vaccine in older adults
}

Janna R. Shapiro ${ }^{1}$, Huifen Li ${ }^{2}$, Rosemary Morgan ${ }^{1}$, Yiyin Chen ${ }^{3}$, Helen Kuo ${ }^{1}$, Xiaoxuan Ning ${ }^{4}$, Patrick Shea ${ }^{5}$, Cunjin $\mathrm{Wu}^{6}$, Katherine Merport ${ }^{7}$, Rayna Saldanha7 ${ }^{7}$, Suifeng Liu ${ }^{8}$, Engle Abrams ${ }^{2}$, Yan Chen ${ }^{9}$, Denise C. Kelly ${ }^{2}$, Eileen Sheridan-Malone ${ }^{2}$, Lan Wang ${ }^{10}$, Scott L. Zeger ${ }^{11}$, Sabra L. Klein ${ }^{1,5^{*}}$, and Sean X. Leng ${ }^{2,5^{*}}$

${ }^{1}$ Department of International Health, Johns Hopkins Bloomberg School of Public Health, Baltimore, MD, USA.

${ }^{2}$ Division of Geriatric Medicine and Gerontology, Department of Medicine, Johns Hopkins University School of Medicine, Baltimore, MD, USA.

${ }^{3}$ Guangdong Geriatrics Institute, Guangdong Provincial People's Hospital, Guangdong Academy of Medical Sciences, Guangzhou, Guangdong, China.

${ }^{4}$ Department of Geriatrics, Xijing Hospital, The Fourth Military Medical University, Xi'an, Shaanxi, China.

${ }^{5}$ W. Harry Feinstone Department of Molecular Microbiology and Immunology, Johns Hopkins Bloomberg School of Public Health, Baltimore, MD, USA.

${ }^{6}$ Department of Geriatrics, The Second Hospital of Tianjin Medical University, Tianjin, Hebei, China.

${ }^{7}$ Zanvyl Krieger School of Arts and Science, Johns Hopkins University, Baltimore, MD, USA.

8 Zhongshan Hospital, Xiamen University, Xiamen, Fujian, China.

${ }^{9}$ Department of Geriatrics, The First Affiliated Hospital of Chongqing Medical University, Chongqing, Sichuan, China.

${ }^{10}$ Department of Geriatrics, The First Affiliated Hospital, Zhejiang University School of Medicine, Hangzhou, Zhejiang, China

${ }^{11}$ Department of Biostatistics, Johns Hopkins Bloomberg School of Public Health, Baltimore, MD, USA.

${ }^{*}$ Corresponding authors

Running title: Age, sex, and humoral immunity to influenza

Key words: age, sex difference, HAl antibody titer, influenza vaccination

Manuscript statistics:

Abstract: 172 words

Main text: 4,818 words

Figure: 5

Tables: 4

References: 70

Contact information: Address correspondence to Sabra Klein (sklein2@jhu.edu) or Sean Leng (sleng1@jhmi.edu) 
medRxiv preprint doi: https://doi.org/10.1101/2021.07.21.21260712; this version posted July 23, 2021. The copyright holder for this preprint (which was not certified by peer review) is the author/funder, who has granted medRxiv a license to display the preprint in perpetuity.

All rights reserved. No reuse allowed without permission.

Shapiro et al.

\section{Abstract}

44 Older adults ( $\geq 65$ years of age) bear a significant burden of severe disease and mortality

45 associated with influenza, despite relatively high annual vaccination coverage and substantial

46 pre-existing immunity to influenza. To test the hypothesis that host factors, including age and

47 sex, play a role in determining the effect of repeat vaccination and levels of pre-existing

48 humoral immunity to influenza, we evaluated pre- and post-vaccination strain-specific

49 hemagglutination inhibition (HAl) titers in adults over 75 years of age who received a high-dose

50 influenza vaccine in at least four out of six influenza seasons (NCT02200276). Neither age, sex,

51 body mass index, frailty, nor repeat vaccination were significantly associated with post-

52 vaccination HAl titer outcomes. Pre-vaccination titers, however, were significantly predictive of

53 post-vaccination outcomes. Pre-vaccination titers to H1N1 remained constant with age, while

54 those to H3N2 and influenza B decreased substantially with age in males but not in females.

55 Our findings highlight the importance of pre-existing immunity in this highly vaccinated older

56 adult population and suggest that older males are particularly vulnerable to reduced pre-

57 existing humoral immunity to influenza from previous annual vaccination. 
medRxiv preprint doi: https://doi.org/10.1101/2021.07.21.21260712; this version posted July 23, 2021. The copyright holder for this preprint (which was not certified by peer review) is the author/funder, who has granted medRxiv a license to display the preprint in perpetuity.

All rights reserved. No reuse allowed without permission.

Shapiro et al.

$\underline{\text { Introduction }}$

Seasonal influenza is an important public health burden in older adults (people $\geq 65$ years of age), particularly the oldest and frail subset ${ }^{1-3}$. In the United States (U.S.), there are an estimated 4 million incident cases per year in older adults, accounting for $90 \%$ of deaths associated with influenza ${ }^{4,5}$. The U.S. Centers for Disease Control and Prevention (CDC) recommends annual influenza vaccination for prevention of influenza infection and complications in people 6 months and older 6 . The high-dose inactivated influenza vaccine (HDIIV) is available to older adults and has demonstrated superior efficacy over standard-dose vaccines in this vulnerable age group ${ }^{6,7}$. Seasonal influenza vaccine coverage is relatively high in

67 older adults, with $>60 \%$ of older Americans vaccinated annually, compared to $<40 \%$ of the 18 49 age group $^{8}$. Age-related immunosenescence, defined by a decline in cellular and humoral immune function combined with a chronic low-grade inflammatory phenotype (CLIP) ${ }^{9-11}$, is believed to

71 be the primary reason for the reduced effectiveness of influenza vaccines observed in older

72 adults ${ }^{12-14}$. Repeated annual vaccination may also have a negative effect on vaccine-induced

73 humoral immune responses as well as vaccine effectiveness (VE). For example, a recent

74 observational test-negative study using ten years of vaccination history found that in older

75 adults, VE decreased with increasing numbers of previous vaccinations but that vaccination

76 continued to offer some level of protection ${ }^{15}$. Another study over eight seasons in the general

77 adult population found that VE to H3N2, but not influenza B, was reduced among individuals

78 with frequent vaccination history compared to those without prior vaccination ${ }^{16}$. The impact of 
medRxiv preprint doi: https://doi.org/10.1101/2021.07.21.21260712; this version posted July 23, 2021. The copyright holder for this preprint (which was not certified by peer review) is the author/funder, who has granted medRxiv a license to display the preprint in perpetuity.

All rights reserved. No reuse allowed without permission.

Shapiro et al.

4

80 effects of repeat vaccination overall; however, when negative effects were observed, they were

81 most pronounced for $\mathrm{H} 3 \mathrm{~N} 2{ }^{17}$. In contrast, a recent systematic review and meta-analysis

82 concluded that the available evidence does not support a reduction in VE with consecutive

83 repeat vaccination, but that certainty in the evidence was low ${ }^{18}$. Case control studies in both

84 Australia and Spain found beneficial effects of repeated annual vaccination on VE in older

85 adults ${ }^{19,20}$, and an observational population-based study in Sweden found no differences in VE

86 between those who had been vaccinated in the current season only and those who had been

87 vaccinated in both the current and previous seasons ${ }^{21}$. Based on the conflicting evidence,

88 multi-season clinical studies to address the effects of aging and repeated vaccination have been

89 recommended ${ }^{17}$.

Mechanistically, pre-existing immunity generated to various influenza virus exposures

91 over time can have an important impact on the outcome of vaccination. According to immune

92 imprinting theory, the memory response established by an individual's first influenza exposure

93 has a lifelong effect on subsequent immune responses to infection or vaccination ${ }^{22}$. Broad pre-

94 existing immunity is thought to have negative consequences, as pre-existing antibodies can

95 suppress the response to novel influenza virus strains by reducing the amount of available

96 antigen or epitope masking ${ }^{23,24}$. A theoretical benefit of HD-IIV is that pre-existing antibodies

97 cannot sequester the increased amount of antigen delivered, and, thus, more antigen is

98 available to activate memory B cells and elicit a protective response ${ }^{25-27}$. To our knowledge,

99 however, the impact of pre-existing immunity in the context of the HD-IIV has not been

100 adequately characterized. 
medRxiv preprint doi: https://doi.org/10.1101/2021.07.21.21260712; this version posted July 23, 2021. The copyright holder for this preprint (which was not certified by peer review) is the author/funder, who has granted medRxiv a license to display the preprint in perpetuity.

All rights reserved. No reuse allowed without permission.

Shapiro et al. 5

101

102

103

104

105

106

107

108

109

110

111

112

113

114

115

116

117

118

119

120

121 clinical characteristics of the study participants. There was a slight predominance of females

122 (55.6\%), and yearly study enrollment increased over time. Baseline characteristics, measured

can impact vaccine responses in older adults. Females have been found to mount greater

antibody responses to HD-IIV than males ${ }^{28}$. The relationship between frailty and influenza

vaccine responses is debated in the literature, with one study reporting frailty having a negative

effect $^{29}$, others reporting no effect ${ }^{30-34}$, and others still reporting a positive effect ${ }^{35}$. Finally, in

older adults, obesity is significantly associated with decreased hemagglutination inhibition (HAI)

titers and percentage of switched memory B cells ${ }^{36}$. We hypothesize that the variation across

studies in estimates of the effects of pre-existing immunity and repeat annual vaccination is

partly caused by failure to adequately account for heterogeneity and interactions among host

factors that likely differ across studies. To address this knowledge gap, we used a longitudinal

cohort of older adults over 75 years of age who had received high-dose, trivalent inactivated

influenza vaccine (HD-IIV3) in at least four out of six influenza seasons to estimate the impact of

repeat vaccination on the antibody response to HD-IIV3 and its dependence on the intersection

of age, sex, frailty, BMI, pre-existing immunity.

$\underline{\text { Results }}$

Study Participants and annual influenza immunization with HD-IIV3

Over the six influenza seasons from 2014-2015 to 2019-2020, 90 individuals participated in at least four study seasons and 433 doses of HD-IIV3 were. The strains included in each

vaccine and the study protocol are described in Figure 1. Table 1 shows demographic and 
medRxiv preprint doi: https://doi.org/10.1101/2021.07.21.21260712; this version posted July 23, 2021. The copyright holder for this preprint (which was not certified by peer review) is the author/funder, who has granted medRxiv a license to display the preprint in perpetuity.

All rights reserved. No reuse allowed without permission.

Shapiro et al.

6

123 during the first year of participation, were similar between males and females. The median age

124 at study enrollment was 80 , and $>50 \%$ of participants were classified as pre-frail as per the

125 Frailty Phenotype ${ }^{37}$. Trends in the change in frailty since baseline, calculated as the difference

126 between the first and last years of participation, differed by sex. A greater proportion of males

127 improved in frailty status, whereas more females either did not change or progressed in frailty

128 status. A greater proportion of males also experienced changes in BMI over the course of the

129 study, while BMI did not change for females.

130

131

Pre- and post-vaccination strain-specific HAl titers are high among repeatedly vaccinated

older adults

Pre- and post-vaccination strain-specific HAl titer outcomes to the three HD-IIV3 vaccine

134 antigens are summarized and disaggregated by sex in Table 2. As expected in this highly

vaccinated elderly population, titers and seroprotection rates (defined as an HAI titer $\geq 40^{38-40}$ )

136 were high. This was particularly true for influenza B, where $98 \%$ of the participants were

137 seroprotected prior to immunization. Post-vaccination, $>94 \%$ of participants achieved

138 seroprotection for $\mathrm{H} 1 \mathrm{~N} 1$ and $\mathrm{H} 3 \mathrm{~N} 2$, while $100 \%$ of participants were seroprotected against

139 influenza B. Because of the lack of variability in post-vaccination seroprotection, this outcome

140 was omitted from further analysis. Fold-rise in titers and rates of seroconversion, as defined by

$141 \geq 4$-fold titer increase ${ }^{41}$, were relatively low but were highest for H3N2. There were no sex

142 differences in any post-vaccination outcomes. Together, these data indicate that pre-existing

143 and post-vaccination strain-specific HAl titers remained high among older adults who were

144 repeatedly vaccinated with HD-IIV3. 
medRxiv preprint doi: https://doi.org/10.1101/2021.07.21.21260712; this version posted July 23, 2021. The copyright holder for this preprint (which was not certified by peer review) is the author/funder, who has granted medRxiv a license to display the preprint in perpetuity.

All rights reserved. No reuse allowed without permission.

Shapiro et al. 7

Age, sex, BMI, frailty status and repeat vaccination are not associated with post-vaccination

outcomes

We then assessed the relationships between pre-defined host factors (i.e., age, sex,

BMI, and frailty status) and post-vaccination strain-specific HAl titer outcomes. When

controlling for pre-vaccination titers and study year, neither age, frailty, nor BMI were

151 individually statistically-significantly associated with post-vaccine titers (Figure 2A-C), the fold-

152 rise in titers (Figure 2D-F), or the odds of seroconversion (Figure 2G-I) for either H1N1, H3N2 or

153 influenza B. Inclusion of interaction terms in the models allowed for analysis of sex-specific

154 contributions of age, frailty, and BMI as well as sex differences in the effects of these host

155 factors. None of the host factors had a statistically significant association with post-vaccination

156 outcomes for either males or females, and no statistically significant sex differences in post-

157 vaccination outcomes were observed.

The relationship between the number of years of study participation and post-

vaccination $\mathrm{HAl}$ titers outcomes was investigated to address the concern of potential negative

160 effects of repeated annual vaccination on the humoral immune response to future vaccines.

161 Vaccination status prior to study enrollment could not be verified, but leveraging the

162 longitudinal design of our study, we sought to quantify whether post-vaccination outcomes

163 declined with additional annual vaccination, and whether this effect differed by sex. There was

164 generally a negative trend between the number of years participated and post-vaccination

165 titers (Figure 3A-D), fold rise in titers (Figure 3E-H), and odds of seroconversion (Figure 3I-L);

166 these decreases, however, were not statistically significant. 
medRxiv preprint doi: https://doi.org/10.1101/2021.07.21.21260712; this version posted July 23, 2021. The copyright holder for this preprint (which was not certified by peer review) is the author/funder, who has granted medRxiv a license to display the preprint in perpetuity.

All rights reserved. No reuse allowed without permission.

Shapiro et al. 8

Two interesting trends emerged from this analysis. First, the effect sizes were smaller

168 (i.e., closer to the null) for influenza B than for either H1N1 or H3N2, suggesting that the impact

169 of repeat vaccination may vary by influenza subtype. Secondly, there was a significant sex

170 difference in the effect of increasing years of vaccination on the odds of seroconverting to

$171 \mathrm{H} 3 \mathrm{~N} 2$ (difference in log odds $=0.38 ; p=0.023)$. While there was no effect in females $(\mathrm{OR}=$

$1720.988 ; p=0.959)$, the odds of seroconverting to H3N2 decreased by $33 \%$ for each additional

173 year of study participation for males $(O R=0.673 ; p=0.100)$ (Figure 3K-L). Therefore, in

174 addition to varying by virus subtype, the mechanisms through which repeated vaccination

175 affects antibody responses may be sex-specific.

176

177 Pre-vaccination HAI titers strongly predict post-vaccination outcomes

178 Overall, host factors and increasing years of vaccination did not significantly predict any

179 of the post-vaccination antibody titer parameters. Pre-vaccination titers, however, were strong

180 predictors of post-vaccination titers for $\mathrm{H} 1 \mathrm{~N} 1$ (slope $=0.49 ; 95 \% \mathrm{Cl}: 0.41 ; 0.58$ ) (Figure $4 \mathrm{~A}$ ),

$181 \mathrm{H} 3 \mathrm{~N} 2$ (slope $=0.59 ; 95 \% \mathrm{Cl}: 0.52 ; 0.66$ ) (Figure 4B), and influenza $\mathrm{B}$ (slope $=0.57 ; 95 \% \mathrm{Cl}: 0.50$;

$1820.63)$ (Figure 4C) ( $p<0.0001$ for testing the null hypotheses that the slope is zero for each

183 antigen). Conversely, there was a strong negative association between pre-vaccination titers

184 and the fold-rise for H1N1 (slope $=-0.15 ; 95 \% \mathrm{Cl}: 0.18 ; 0.13$ ) (Figure 4D), H3N2 (slope = -0.12 ;

$18595 \% \mathrm{Cl}:-0.15 ;-0.10$ ) (Figure 4E), and influenza B (slope $=-0.13 ; 95 \% \mathrm{Cl}:-0.15 ;-0.11$ ) (Figure 4F)

186 ( $p<0.0001$ for testing the null hypotheses that the slope to zero for all antigens), such that

187 greater pre-vaccination titers were associated with a smaller fold rise. Finally, there was a

188 similar negative association between pre-vaccination titers and the odds of seroconverting for 
medRxiv preprint doi: https://doi.org/10.1101/2021.07.21.21260712; this version posted July 23, 2021. The copyright holder for this preprint (which was not certified by peer review) is the author/funder, who has granted medRxiv a license to display the preprint in perpetuity.

Shapiro et al. $\quad 9$

H1N1 (OR = 0.31; 95\% Cl: 0.21; 0.46) (Figure 4G), H3N2 (OR=0.60; 95\% Cl: 0.50; 0.71) (Figure

4H), and influenza $B(O R=0.41 ; 95 \% \mathrm{Cl}: 0.31 ; 0.55)$ (Figure $4 \mathrm{I})(p<0.0001$ for testing the null hypothesis that the odds ratio is equal to one for all antigens).

The strength of these associations suggests that post-vaccination outcomes are primarily determined by pre-existing humoral immunity. Thus, in highly vaccinated populations, such as the older adult participants in this study, pre-vaccination titers are not just confounders to be controlled for in the analysis of post-vaccination humoral immunity but are an outcome of public health importance that illustrate durability of immunity to influenza from one season to the next. Given the importance of pre-vaccination titers, we focused subsequent analyses on exploring the relationships between host factors and pre-vaccination HAl titers in the context of repeat annual vaccination.

\section{Sex modifies the relationship between age and pre-vaccination HAI titers}

(Figure 5A-C). Neither frailty nor BMI were statistically significantly associated with pre-

vaccination HAl titers for all participants or in sex-disaggregated subgroup analysis. Further, there were no statistically significant sex differences in the effects of frailty or BMI on pre-

vaccination $\mathrm{HAl}$ titers against either $\mathrm{H} 1 \mathrm{~N} 1, \mathrm{H} 3 \mathrm{~N} 2$, or influenza B. A statistically significant sex by which HAl titers declined with age among male but not female participants.

To further interrogate the sex-specific effects of aging, expanded models controlling for frailty and BMI, in addition to study year, were constructed. Coefficients from the base (i.e., 
medRxiv preprint doi: https://doi.org/10.1101/2021.07.21.21260712; this version posted July 23, 2021. The copyright holder for this preprint (which was not certified by peer review) is the author/funder, who has granted medRxiv a license to display the preprint in perpetuity.

All rights reserved. No reuse allowed without permission.

Shapiro et al. 10

211 controlling for study year only) and expanded models are shown in Table 3, and results from

212 expanded models are plotted in Figure 5D-F. For H1N1, HAl titers tended to increase with age

213 for both males and females, but the increase was not statistically significant (males: 0.49 units

214 per decade, $p=0.152$; females: 0.35 units per decade, $p=0.267)$, nor was the sex difference in

215 slope $(p=0.676)$ (Figure 5D). For H3N2, while titers again tended to increase with age in

216 females $(0.62$ units per decade, $p=0.121)$, there was a decreasing trend with age in males $(-$

2170.75 units per decade, $p=0.097$ ), leading to a significant sex difference in age slopes (sex by age

218 interaction $=0.137 ; p=0.010$ ) (Figure 5E). For influenza $B$, titers again tended to increase with

219 age in females ( 0.33 units per decade, $p=0.275)$ but decreased by 0.78 units per decade in

220 males $(p=0.023$ ) (Figure 5F). Like H3N2, the sex difference in the effect of age was significant

221 for influenza B $(p=0.005)$.

222

Both the base and expanded models were then amended to include cubic splines to

223 obtain more granular estimates of the effects of age on HAl titers for males and females.

224 Coefficients for both base and expanded non-linear models are shown in Table 3, and results

225 from expanded models are plotted in Figure 5G-I. The non-linear model for H1N1 did not differ

226 from the linear model, and no significant effects of age within each sex or difference between

227 the sexes were observed (Figure 5G). Although the trends in the linear models were similar for

228 H3N2 and influenza B, using age as a non-linear predictor revealed that different age categories

229 were driving the overall effects. For H3N2, the increase in pre-vaccination HAl titers with age in

230 females was driven by individuals in the $80-85$ age category (increase of 0.67 units; $p=0.037$ ),

231 and the decrease in males was driven primarily by people in the 75-80 age category (decrease

232 of 1.78 units; $p=0.012$ ) (Figure 5.H). Thus, the sex difference was greatest at the younger end 
medRxiv preprint doi: https://doi.org/10.1101/2021.07.21.21260712; this version posted July 23, 2021. The copyright holder for this preprint (which was not certified by peer review) is the author/funder, who has granted medRxiv a license to display the preprint in perpetuity.

All rights reserved. No reuse allowed without permission.

Shapiro et al. 11

233 of the cohort ( $p=0.036$ at 75 years of age). Conversely, increasing titers to influenza B with age

234 in females were driven by individuals in the 75-80 age category (increase of 1.2 units; $p=$

235 0.004), whereas for males there was a sharp decline in HAl titers that occurred in participants

$23690-95$ years of age (decrease of 1.65 units; $p<0.0001$ ) (Figure 5.I). Here, the sex difference in

237 pre-vaccination titers was only significant at the oldest end of the cohort $(p=0.003$ at 95 years

238 of age). Taken together, these data illustrate sex-specific effects of aging on pre-vaccination

239 antibody titers to H3N2 and influenza B, but not H1N1.

240

241 Controlling for sex leads to incorrect interpretations

242 The impact of sex as a biological variable is often ignored in biomedical research ${ }^{42,43}$.

243 This is particularly true in the context of aging, where attention is typically directed to

244 immunosenescence, failing to recognize that aging can have distinct effects on immune

245 function in males and females ${ }^{44-46}$. In this analysis, a priori hypotheses regarding sex differences

246 in the effect of age guided the inclusion of age by sex interaction terms in all models. To

247 illustrate the consequences of ignoring sex as a biological variable, however, analyses were

248 repeated controlling for sex rather than allowing age effects to vary by sex. For H3N2 and

249 influenza B, where the effect of aging was found to be statistically significantly different in

250 males as compared to females, the estimates derived by controlling for sex (black lines in Figure

$2515 \mathbf{E}, \mathbf{F}, \mathbf{H}, \mathbf{I}$ ) were not representative of either sex. In the linear models, for example, controlling

252 for sex led to the incorrect inference that titers remain constant with age, while the interaction

253 models demonstrate that this is false for both males and females. 
medRxiv preprint doi: https://doi.org/10.1101/2021.07.21.21260712; this version posted July 23, 2021. The copyright holder for this preprint (which was not certified by peer review) is the author/funder, who has granted medRxiv a license to display the preprint in perpetuity.

All rights reserved. No reuse allowed without permission.

Shapiro et al. 12

In addition to conceptual reasons to interrogate sex differences, inclusion of interaction

terms improved the goodness-of-fit of statistical models. Goodness-of-fit of eight models for

each vaccine antigen were compared using Akaike's Information Criterion (AIC) in Table 4,

257 where lower values indicate better relative goodness-of-fit. For antibody titers to H3N2 and

258 influenza B, despite the penalty for increasing model complexity, fit was improved by including

259 an age-sex interaction term, and the best models overall were expanded models that allowed

260 the effect of age to differ by sex. Thus, incorporating sex differences into vaccinology research

261 can lead to more robust analysis.

262

263

\section{Discussion}

In this multi-season, longitudinal study of older adults over 75 years of age, we observed

265 no statistically significant associations of age, sex, BMI, frailty, or the number of years of repeat

266 annual vaccination with any post-vaccination HAl titer outcomes. Importantly, this suggests

267 that repeat annual vaccination with HD-IIV3 does not seem to have significant positive or

268 negative effects on strain-specific HAl antibody responses in the highly vaccinated elderly

269 population but may mask the impact of other factors. Interestingly, there was some evidence to

270 suggest that particularly for $\mathrm{H} 3 \mathrm{~N} 2$, the effect of repeat vaccination does vary by sex, thus

271 supporting our hypothesis that variability in estimates of the effect of repeat vaccination in the

272 literature is caused by failure to adequately account for the contribution of host factors.

Pre-vaccination titers strongly predicted all post-vaccination antibody titer outcomes,

274 indicating that pre-existing humoral immunity, which may reflect the durability of humoral

275 immunity against influenza from previous seasons, is an important outcome measure to

276 consider in the highly vaccinated older adult population. Regarding age as a determinant of pre- 
medRxiv preprint doi: https://doi.org/10.1101/2021.07.21.21260712; this version posted July 23, 2021. The copyright holder for this preprint (which was not certified by peer review) is the author/funder, who has granted medRxiv a license to display the preprint in perpetuity.

All rights reserved. No reuse allowed without permission.

Shapiro et al. 13

277 existing humoral immunity, we found that HAl titers to all three vaccine antigens stayed

278 constant in females with age but that HAl titers to H3N2 and influenza B decreased with age in

279 males, leading to significant sex differences in the effect of age for these two viruses. It has

280 previously been reported that at older ages, there is a male-bias in influenza B infection and

281 hospitalization ${ }^{47,48}$. Our results thus provide a potential mechanism for this sex difference and

282 highlight the need to develop better vaccines or vaccination strategies for older males. Finally,

283 we demonstrated that failing to allow for sex-specific effects would have resulted in invalid

284 conclusions for both males and females.

Because older adults are disproportionally burdened by severe disease and mortality

286 from seasonal influenza, significant effort has been devoted to improving annual vaccination

287 coverage for this vulnerable population. Older adults, particularly those who are over 75 years

288 of age, can thus have decades of repeated annual influenza vaccination. Cumulatively, repeated

289 annual vaccination can lead to high pre-vaccination titers. As expected, over $72 \%$ participants

290 had a pre-vaccination HAl titer of 40 or higher to H1N1 and H3N2, and $98 \%$ participants had

291 such "seroprotection" to influenza B. High pre-existing humoral immunity has important

292 consequences in assessing humoral immune responses to influenza vaccines, as demonstrated

293 by the strong positive relationship between pre- and post-vaccination titers. Conversely, ratio-

294 based outcomes (i.e., fold rise and seroconversion) were negatively associated with pre-

295 vaccination titers, since, by definition, large denominators (pre-vaccination titers) result in

296 smaller ratios. We recently reported a similar effect in younger adult healthcare workers, where

297 mandatory vaccination policies result in exceptionally high rates of immunization ${ }^{49}$. While some

298 argue that high levels of pre-existing antibodies interfere with the generation of de novo 
medRxiv preprint doi: https://doi.org/10.1101/2021.07.21.21260712; this version posted July 23, 2021. The copyright holder for this preprint (which was not certified by peer review) is the author/funder, who has granted medRxiv a license to display the preprint in perpetuity.

All rights reserved. No reuse allowed without permission.

Shapiro et al. 14

299 immune responses ${ }^{24,27}$, others suggest that ratio-based measures simply do not appropriately

300 control for imbalances in levels of pre-existing humoral immunity ${ }^{50}$. Following the latter

301 interpretation, a "ceiling effect" is evident in our data, whereby the limit of detection of the

302 assay prohibits observing seroconversion or a large fold-rise in individuals with high levels of

303 pre-existing humoral immunity. Particularly important in older adults, where formation of de

304 novo responses is impaired by immunosenescence ${ }^{51}$, the breadth of pre-existing humoral

305 immunity and the positive predictive value for post-vaccination titers can thus be harnessed to

306 elicit protection ${ }^{26}$. The clinical and scientific implications of this notion are far-reaching and

307 long-term, as the Advisory Committee on Immunization Practices (ACIP) of the CDC has

308 recommended annual influenza vaccination for anyone aged 6 months and older since $2010^{52}$.

309 For many vaccines, antibody titers wane over time ${ }^{53-56}$. Influenza vaccines are unique in

310 this respect due to the recommendation for yearly immunization and exceptional antigenic

311 diversity, which alter the dynamics of waning immunity. The constant pre-vaccination HAI titers

312 with age in females seen in our study suggest that females benefit from a booster effect from

313 each successive annual vaccination that appears to prevent antibody waning. This influenza-

314 specific effect has been reported elsewhere, where samples collected from individuals over a

315 20-year period revealed longitudinal increases in neutralizing titers to influenza ${ }^{57}$. As an

316 explanation for their findings, the authors suggest that even as viral antigens drift over time,

317 many epitopes remain conserved. These conserved epitopes stimulate memory B cells that

318 were generated in response to previous exposures, thus periodically boosting steady-state

319 immunity ${ }^{57}$. However, our data suggest that this effect is absent in males for H3N2 and

320 influenza B. The reasons for this sex difference are unknown, but may be attributable to the 
medRxiv preprint doi: https://doi.org/10.1101/2021.07.21.21260712; this version posted July 23, 2021. The copyright holder for this preprint (which was not certified by peer review) is the author/funder, who has granted medRxiv a license to display the preprint in perpetuity.

All rights reserved. No reuse allowed without permission.

Shapiro et al. 15

321 compounding effects of females developing stronger responses to influenza infection and

322 vaccination throughout adulthood ${ }^{58}$, leading to a more robust repertoire of memory $B$ cells that

323 recognize conserved epitopes on drifted virus strains. It is speculated that in older adults,

324 consistently inferior responses among males may manifest as a lack of memory B cells that can

325 be boosted by drifted viruses to counteract waning of antibody over time, thus resulting in

326 decreasing pre-vaccination titers with age.

Notably the sex difference was absent for H1N1. A possible explanation for this lies in

328 the differing evolutionary rates of the three viral strains. H1N1 experiences slower evolution

329 than $\mathrm{H} 3 \mathrm{~N}^{59}$ and the influenza B/Victoria lineage ${ }^{60}$. In addition, the global co-circulation of

$330 \mathrm{~B} /$ Yamagata and B/Victoria lineages leads to increased exposure to divergent antigens ${ }^{61}$.

331 Accordingly, over the six influenza seasons included in our study, vaccine antigens were

332 significantly more variable for H3N2 and influenza B than for H1N1. While three H1N1 strains

333 were included in seasonal vaccines, five H3N2 strains and four influenza B strains were included

334 over the six study years. A decade-long review of the number of divergent vaccine strains that

335 our study participants may have been exposed to indicates that since 2010, the number of

$336 \mathrm{H} 1 \mathrm{~N} 1$ vaccine strains remained at a total of three, while seven H3N2 strains and five influenza B

337 were used in trivalent vaccines over this period ${ }^{62}$. It is thus possible that repeated exposure to

338 the same H1N1 antigen sufficiently boosted male steady-state immunity to mask sex

339 differences in the immune response. Conversely, for H3N2 and influenza B, sequential exposure

340 to drifted virus strains required robust and broad responses to allow for boosting of steady-

341 state immunity, which may have only been present in females. 
medRxiv preprint doi: https://doi.org/10.1101/2021.07.21.21260712; this version posted July $23,2021$. The copyright holder for this preprint (which was not certified by peer review) is the author/funder, who has granted medRxiv a license to display the preprint in perpetuity.

All rights reserved. No reuse allowed without permission.

Shapiro et al. 16

Another possible explanation is immunological imprinting in youth, as it has a lifelong

343 impact on subsequent immune responses to influenza infection and vaccination ${ }^{22,63}$. Individuals

344 in our cohort, born from 1916-1941, may have been exposed to H1N1 in their youth, while the

3451918 pandemic virus continued to circulate, but were likely exposed to H3N2 and influenza B

346 later in life ${ }^{64}$. Accordingly, older adults are more likely to have HAl activity against historical

347 strains of $\mathrm{H} 1 \mathrm{~N} 1$ viruses than younger subjects, but also have more restricted reactivity to

348 historical H3N2 viruses ${ }^{65}$. Older cohorts are also relatively protected against symptomatic H1N1

349 infection compared to younger cohorts, but this pattern is reversed for $\mathrm{H} 3 \mathrm{~N} 2^{66,67}$. It is therefore

350 possible that strong immune imprinting to H1N1 virus strains masked the sex differences

351 otherwise observed for H3N2 and influenza B.

Our study had several strengths and limitations. First, this was an observational study

353 that was not specifically designed to interrogate sex differences in the immune response to

354 influenza vaccination. To overcome small yearly sample sizes, six influenza seasons were pooled

355 together, and statistical methods were used to control for annual variation in vaccine viruses

356 and repeated measurements on participants. The resulting multi-season nature of this work

357 improves generalizability to future influenza seasons. Secondly, the humoral immune response

358 to vaccination was solely based on strain-specific HAl titers, which are the standard in the field,

359 but lack the functional quality of microneutralization assays ${ }^{68}$. Relying solely on serological

360 samples also prohibited more in-depth mechanistic investigation at the cellular level. Third, the

361 lack of racial diversity in our cohort must be noted, as it prohibited us from investigating race as

362 a host factor of interest, which should be considered in future studies. Although the study

363 lacked racial diversity, the cohort was diverse in terms of age at vaccination, allowing us to 
medRxiv preprint doi: https://doi.org/10.1101/2021.07.21.21260712; this version posted July 23, 2021. The copyright holder for this preprint (which was not certified by peer review) is the author/funder, who has granted medRxiv a license to display the preprint in perpetuity.

All rights reserved. No reuse allowed without permission.

Shapiro et al. 17

364 study effects in the 'oldest' old subset. Finally, a major strength of this study is the

365 intersectional approach to this analysis, which allowed for interrogation of effects both

366 between and within groups (i.e., between and among males and females), leading to a richer

367 and more nuanced interpretation ${ }^{69}$.

In conclusion, we demonstrated that in highly vaccinated older adults, pre-vaccination

369 HAl titers, rather than age, sex, BMI, frailty, or repeat vaccination, predict post-vaccination

370 parameters of humoral immunity. Further, these pre-vaccination titers change with age in a

371 sex-specific manner such that older males are particularly vulnerable to lower levels of pre-

372 existing humoral immunity. Further research should focus on elucidating the mechanisms

373 underlying this sex difference, as well as novel vaccination strategies to harness the breadth of

374 pre-existing immunity in older adults and better protect this vulnerable population.

375

376 Methods

377 Study population and protocol

During the 2014-2015 to 2019-2020 influenza seasons, we enrolled community-dwelling

379 older adults above 75 years of age who had not yet received a seasonal influenza vaccine.

380 Individuals who had a history of allergic reaction to influenza vaccines or to eggs, were

381 currently taking oral steroids or had worsening or new-onset of immune-modulating conditions

382 were excluded. Study participants came to the Clinical Research Unit at Johns Hopkins Institute

383 of Clinical and Translational Research on the Johns Hopkins Bayview Medical Center campus, or

384 study visits were done at participants' home as needed. A detailed medical history was

385 obtained, vital signs were measured and frailty was assessed as per the Frailty Phenotype ${ }^{37}$. 
medRxiv preprint doi: https://doi.org/10.1101/2021.07.21.21260712; this version posted July 23, 2021. The copyright holder for this preprint (which was not certified by peer review) is the author/funder, who has granted medRxiv a license to display the preprint in perpetuity.

All rights reserved. No reuse allowed without permission.

Shapiro et al. 18 registered on clinicaltrials.gov (NCT02200276).

\section{Hemagglutination inhibition assays}

A validated $\mathrm{HAl}$ assay was used to quantify antibody titers against study vaccine antigens for the three vaccine strains ( $\mathrm{H} 1 \mathrm{~N} 1, \mathrm{H} 3 \mathrm{~N} 2$ and $\mathrm{B})$ in each year and were performed by was inhibited.

405

\section{Definitions and categorization of predictor variables}


medRxiv preprint doi: https://doi.org/10.1101/2021.07.21.21260712; this version posted July 23, 2021. The copyright holder for this preprint (which was not certified by peer review) is the author/funder, who has granted medRxiv a license to display the preprint in perpetuity.

All rights reserved. No reuse allowed without permission.

Shapiro et al. 19

Sex was used as a dichotomous variable based on self-report. Age was calculated based

on the date of vaccination and used as a continuous variable. The frailty assessment was based

on the presence or absence of five measurable characteristics: slowed motor performance (by

410 walking speed), poor endurance and energy (by self-report of exhaustion), weakness (by grip

411 strength), shrinking (by unintentional weight loss), and low physical activity (self-report) ${ }^{29,37}$.

412 Participants with three or more out of these five characteristics were defined as frail, those

413 with one or two as prefrail, and those with none as non-frail. BMI was calculated based on

414 measured height and weight and used as a continuous variable. Study year refers to the

415 influenza season (i.e., 2014-2015 to 2019-2020) and was used as categorical variable so as not

416 to imply a linear relationship from year-to-year. Number of years of study participation was

417 defined as the number of vaccines administered to an individual as part of the study and was

418 used as a continuous variable ranging from 1 to 6.

Outcome variables

Geometric mean titers were calculated both pre- and post-vaccination. For regression

422 analysis, titers were transformed to a $\log _{2}$ scale to achieve an approximately normal

423 distribution. The fold-rise in titer was calculated as post-vaccination titers divided by pre-

424 vaccination titers, and $\log _{10}$ transformed to achieve a normal distribution. Seroconversion was

425 defined as achieving a fold-rise $\geq 4$ and used as a binary outcome. Seroprotection was defined as

426 a titer $\geq 1: 40$ and used as a binary outcome.

427 
medRxiv preprint doi: https://doi.org/10.1101/2021.07.21.21260712; this version posted July 23, 2021. The copyright holder for this preprint (which was not certified by peer review) is the author/funder, who has granted medRxiv a license to display the preprint in perpetuity.

All rights reserved. No reuse allowed without permission.

Shapiro et al. 20

\section{Statistical analysis}

To account for repeated measures on participants, multi-level mixed effects models

431 with random intercepts on the individual were used. Following standard risk factor analysis

432 procedure, the contributions of host factors of interest were first assessed individually. Based

433 on the a priori hypotheses of this analysis, fixed effects of the base models for post-vaccination

434 outcomes adjusted for study year, pre-vaccination titers and included interaction terms to

435 allow the effect of the host factor to differ for males and females. Fixed effects of the base

436 models for pre-vaccination titers adjusted for study year and included interaction terms to

437 allow effects to differ by sex. Where significant sex differences were found, further analysis

438 controlled for additional covariates, and used cubic B-splines to investigate non-linear

439 relationships ${ }^{71}$. The relative goodness-of-fit of various models were compared using Akaike's

440 Information Criterion. For graphs, predictions were capped at 95 years of age due to low

441 sample size and large uncertainty in estimates above 95 years. Coefficients were considered

442 statistically significant if 95\% confidence intervals did not span the null value of zero (i.e.,

$443 \mathrm{p}<0.05)$. Analysis was performed in Stata 15 (StataCorp).

445 Data Availability

447 author upon request. 
medRxiv preprint doi: https://doi.org/10.1101/2021.07.21.21260712; this version posted July 23, 2021. The copyright holder for this preprint (which was not certified by peer review) is the author/funder, who has granted medRxiv a license to display the preprint in perpetuity.

All rights reserved. No reuse allowed without permission.

Shapiro et al. 21

Studies Unit and the Johns Hopkins University Institute for Clinical and Translational Research.

The authors would also like to than Dr. Andrew Pekosz for helpful discussion and feedback.

Sanofi Pasteur provided HD-IIV3 and performed HAI testing, but remained blinded to the results

454 and had no further scientific input. This work was supported in part by National Institute of

455 Health (NIH)/National Institute of Allergy and Infectious Diseases R01 Al108907 to S.X.L.,

$456 \mathrm{NIH}$ /National Institute on Aging Specialized Center of Research Excellence U54 AG062333

457 awarded to S.L.K., and funding from Irma and Paul Milstein Program for Senior Health, Milstein

458

459

460

461

fellowship awards from MMAAP Foundation of USA (www.mmaapf.org).

Medical Asian American Partnership (MMAAP) Foundation of USA to S.X.L. J.R.S was supported

by a training award from the Fonds de recherche du Québec - Santé (File \#287609). C.J.W,

X.X.N, and S.F.L. were supported by Irma and Paul Milstein Program for Senior Health

462

\section{Author contributions}

464 S.X.L. designed and oversaw the study. E.A., D.C.K. and E.S-M collected data and biological

465 samples. H.F.L., Y.Y.C., Y.C., C.J.W., X.X.N., L.W., and S.F.L. processed biological samples. J.R.S.,

466 K.M., and R.S. entered and cleaned data. J.R.S. conceived of analytical approach and

467 experimental questions and performed analyses under mentorship of S.L.Z, R.M., and S.L.K.

468 K.M., H.K., and P.S. contributed to analyses. J.R.S. wrote the manuscript, with significant

469 editorial contributions and discussion from S.L.K., R.M., S.L.Z., and S.X.L. All authors reviewed, 
medRxiv preprint doi: https://doi.org/10.1101/2021.07.21.21260712; this version posted July 23, 2021. The copyright holder for this preprint (which was not certified by peer review) is the author/funder, who has granted medRxiv a license to display the preprint in perpetuity.

All rights reserved. No reuse allowed without permission.

Shapiro et al. 22

470

471

472

473

474

475

476

4771 Macias, A. E. et al. The disease burden of influenza beyond respiratory illness. Vaccine

478

479

480

481

482

483

484

485

486

487

488

489

490

491

492

493

494

495

496

497

498

499

500

501

502

503

504

505

506

507

edited, and approved the final draft of the manuscript. All authors are accountable for the

accuracy and integrity of the work.

\section{Competing Interests Statement}

The authors have no competing interests to declare.

\section{References} (2020).

2 Iuliano, A. D. et al. Estimates of global seasonal influenza-associated respiratory mortality: a modelling study. Lancet 391, 1285-1300 (2018).

3 Global Burden of Disease Influenza Collaborators et al. Mortality, morbidity, and hospitalisations due to influenza lower respiratory tract infections, 2017: an analysis for the Global Burden of Disease Study 2017. Lancet Respir Medicine 7, 69-89, doi:10.1016/s2213-2600(18)30496-x PMID - 30553848 (2018).

4 Gnanasekaran, G., Biedenbender, R., Davidson, H. E. \& Gravenstein, S. Vaccinations for the Older Adult. Clin Geriatr Med 32, 609-625, doi:10.1016/j.cger.2016.03.001 PMID 27394026 (2016).

5 Hamborsky, J., Kroger, A. \& Wolfe, S. Epidemiology and prevention of vaccinepreventable diseases. (US Department of Health \& Human Services, Centers for Disease Control and Prevention 2015).

6 Grohskopf, L. A. et al. Prevention and control of seasonal influenza with vaccines: recommendations of the Advisory Committee on Immunization Practices-United States, 2020-21 influenza season. MMWR Recommendations and Reports 69, 1 (2020).

7 DiazGranados, C. A. et al. Efficacy of High-Dose versus Standard-Dose Influenza Vaccine in Older Adults. New England Journal of Medicine 371, 635-645, doi:10.1056/nejmoa1315727 PMID - 25119609 (2014).

8 Centers for Disease Control and Prevention. (2020).

9 Crooke, S. N., Ovsyannikova, I. G., Poland, G. A. \& Kennedy, R. B. Immunosenescence: A systems-level overview of immune cell biology and strategies for improving vaccine responses. Exp Gerontol 124, 110632, doi:10.1016/j.exger.2019.110632 PMID 31201918 (2019).

10 Weinberger, B. Vaccines for the elderly: current use and future challenges. Immunity \& ageing : I \& A 15, 3, doi:10.1186/s12979-017-0107-2 PMID - 29387135 (2018).

11 Chen, Y., Liu, S. \& Leng, S. X. Chronic low-grade inflammatory phenotype (CLIP) and senescent immune dysregulation. Clinical therapeutics 41, 400-409 (2019).

12 Demicheli, V., Jefferson, T., Ferroni, E., Rivetti, A. \& Di Pietrantonj, C. Vaccines for preventing influenza in healthy adults. Cochrane database of systematic reviews (2018). 
medRxiv preprint doi: https://doi.org/10.1101/2021.07.21.21260712; this version posted July 23, 2021. The copyright holder for this preprint (which was not certified by peer review) is the author/funder, who has granted medRxiv a license to display the preprint in perpetuity.

50813 Nichols, M. K. et al. Influenza vaccine effectiveness to prevent influenza-related

509

510

511

512

513

514

515

516

517

518

519

520

521

522

523

524

525

526

527

528

529

530

531

532

533

534

535

536

537

538

539

540

541

542

543

544

545

546

$547 \quad 25$

548

549

550

551 hospitalizations and serious outcomes in Canadian adults over the 2011/12 through 2013/14 influenza seasons: A pooled analysis from the Canadian Immunization Research Network (CIRN) Serious Outcomes Surveillance (SOS Network). Vaccine 36, 2166-2175, doi:10.1016/j.vaccine.2018.02.093 PMID - 29548608 (2018).

14 Rondy, M. et al. Effectiveness of influenza vaccines in preventing severe influenza illness among adults: a systematic review and meta-analysis of test-negative design casecontrol studies. Journal of Infection 75, 381-394 (2017).

15 Kwong, J. C. et al. The impact of repeated vaccination using 10-year vaccination history on protection against influenza in older adults: a test-negative design study across the 2010/11 to 2015/16 influenza seasons in Ontario, Canada. Eurosurveillance 25, 1900245 (2020).

16 McLean, H. Q. et al. Impact of Repeated Vaccination on Vaccine Effectiveness Against Influenza A(H3N2) and B During 8 Seasons. Clin Infect Dis 59, 1375-1385, doi:10.1093/cid/ciu680 PMID - 25270645 (2014).

17 Belongia, E. A. et al. Repeated annual influenza vaccination and vaccine effectiveness: review of evidence. Expert Review of Vaccines 16, 723-736, doi:10.1080/14760584.2017.1334554 PMID - 28562111 (2017).

18 Bartoszko, J. J. et al. Does consecutive influenza vaccination reduce protection against influenza: A systematic review and meta-analysis. Vaccine 36, 3434-3444, doi:10.1016/j.vaccine.2018.04.049 PMID - 29724509 (2018).

19 Cheng, A. C. et al. Repeated Vaccination Does Not Appear to Impact Upon Influenza Vaccine Effectiveness Against Hospitalization With Confirmed Influenza. Clin Infect Dis 64, 1564-1572, doi:10.1093/cid/cix209 PMID - 28329167 (2017).

20 Casado, l. et al. Repeated influenza vaccination for preventing severe and fatal influenza infection in older adults: a multicentre case-control study. Canadian Medical Association Journal 190, E3-E12, doi:10.1503/cmaj.170910 PMID - 29311098 (2018).

21 Örtqvist, Å., Brytting, M., Leval, A. \& Hergens, M.-P. Impact of repeated influenza vaccinations in persons over 65 years of age: A large population-based cohort study of severe influenza over six consecutive seasons, 2011/12-2016/17. Vaccine 36, 55565564, doi:10.1016/j.vaccine.2018.07.052 PMID - 30076104 (2018).

22 Jang, H. \& Ross, T. M. Preexisting influenza specific immunity and vaccine effectiveness. Expert Review of Vaccines 18, 1-9, doi:10.1080/14760584.2019.1675519 PMID 31575308 (2019).

23 Henry, C., Palm, A.-K. E., Krammer, F. \& Wilson, P. C. From Original Antigenic Sin to the Universal Influenza Virus Vaccine. Trends Immunol 39, 70-79, doi:10.1016/j.it.2017.08.003 PMID - 28867526 (2018).

24 Linderman, S. L. et al. Influenza Immunization in the Context of Preexisting Immunity. Csh Perspect Med, a040964, doi:10.1101/cshperspect.a040964 PMID - 32988981 (2020). 25 Guthmiller, J. J., Utset, H. A. \& Wilson, P. C. B Cell Responses against Influenza Viruses: Short-Lived Humoral Immunity against a Life-Long Threat. Viruses 13, 965 (2021).

26 Guthmiller, J. J. \& Wilson, P. C. Harnessing immune history to combat influenza viruses. Current Opinion in Immunology 53, 187-195, doi:10.1016/j.coi.2018.05.010 PMID 29890370 (2018). 
medRxiv preprint doi: https://doi.org/10.1101/2021.07.21.21260712; this version posted July 23, 2021. The copyright holder for this preprint (which was not certified by peer review) is the author/funder, who has granted medRxiv a license to display the preprint in perpetuity.

All rights reserved. No reuse allowed without permission.

Shapiro et al. 24

55227 Ellebedy, A. H. Immunizing the Immune: Can We Overcome Influenza's Most Formidable

$553 \quad$ Challenge? Nato Adv Sci Inst Se 6, 68, doi:10.3390/vaccines6040068 PMID - 30248996

554 (2018).

55528 Falsey, Ann R., Treanor, John J., Tornieporth, N., Capellan, J. \& Gorse, Geoffrey J.

556

557

558 Randomized, Double-Blind Controlled Phase 3 Trial Comparing the Immunogenicity of High-Dose and Standard-Dose Influenza Vaccine in Adults 65 Years of Age and Older. J Infect Dis 200, 172-180, doi:10.1086/599790 PMID - 19508159 (2009).

559

29 Yao, X. et al. Frailty is associated with impairment of vaccine-induced antibody response

560 and increase in post-vaccination influenza infection in community-dwelling older adults.

561

562 Vaccine 29, 5015-5021, doi:10.1016/j.vaccine.2011.04.077 PMID - 21565245 (2011).

563

564 Narang, V. et al. Influenza Vaccine-Induced Antibody Responses Are Not Impaired by Frailty in the Community-Dwelling Elderly With Natural Influenza Exposure. Front Immunol 9, 2465, doi:10.3389/fimmu.2018.02465 PMID - 30405641 (2018).

31 Epps, P. V. et al. Preexisting Immunity, Not Frailty Phenotype, Predicts Influenza Postvaccination Titers among Older Veterans. Clin Vaccine Immunol 24, e00498-00416, doi:10.1128/cvi.00498-16 PMID - 28100496 (2017).

568

32 Bauer, J. M. et al. Influenza vaccine response in community-dwelling German prefrail and frail individuals. Immun Ageing 14, 17, doi:10.1186/s12979-017-0098-z PMID -

570

571 28694834 (2017).

572

33 Moehling, K. K. et al. The effect of frailty on HAl response to influenza vaccine among community-dwelling adults $\geq 50$ years of age. Hum Vacc Immunother 14, 361-367, doi:10.1080/21645515.2017.1405883 PMID - 29172948 (2017).

$574 \quad 34$

575 Moehling, K. K. et al. The impact of physical frailty on the response to inactivated influenza vaccine in older adults. Aging 12, doi:10.18632/aging.202207 PMID 33347425 (2020). 4-year randomized trial comparing standard and high dose influenza vaccination. Open Forum Infect Dis 7, ofaa148, doi:10.1093/ofid/ofaa148 PMID - 32500087 (2020). Frasca, D. et al. Obesity decreases B cell responses in young and elderly individuals. Obesity 24, 615-625, doi:10.1002/oby.21383 PMID - 26857091 (2016). Fried, L. P. et al. Frailty in Older Adults: Evidence for a Phenotype. Journals Gerontology Ser Biological Sci Medical Sci 56, M146-M157, doi:10.1093/gerona/56.3.m146 PMID 11253156 (2001). tools for the licensure of effective influenza vaccines? Hum Vacc Immunother 14, 647656, doi:10.1080/21645515.2017.1413518 PMID - 29252098 (2018). of antibody against attenuated influenza $A$ viruses using single radial haemolysis. Epidemiology \& Infection 93, 301-312 (1984). Hobson, D., Curry, R., Beare, A. \& Ward-Gardner, A. The role of serum haemagglutination-inhibiting antibody in protection against challenge infection with influenza A2 and B viruses. Epidemiology \& Infection 70, 767-777 (1972). 
medRxiv preprint doi: https://doi.org/10.1101/2021.07.21.21260712; this version posted July 23, 2021. The copyright holder for this preprint (which was not certified by peer review) is the author/funder, who has granted medRxiv a license to display the preprint in perpetuity.

All rights reserved. No reuse allowed without permission.

Shapiro et al. 25

59441 Reber, A. \& Katz, J. Immunological assessment of influenza vaccines and immune

595

596

597

598

599

600

601

602

603

604

605

606

$607 \quad 46$

608

609

610

611

612

613

614

615

616

617

618

619

620

621

622

623

624

625

626

627

628

629

630

631

632

633

$634 \quad 56$

635

$636 \quad 57$

637 correlates of protection. Expert Review of Vaccines 12, 519-536, doi:10.1586/erv.13.35 PMID - 23659300 (2013).

42 Shapiro, J. R., Klein, S. L. \& Morgan, R. Stop 'controlling' for sex and gender in global health research. Bmj Global Heal 6, e005714, doi:10.1136/bmjgh-2021-005714 (2021).

43 Klein, S. L., Jedlicka, A. \& Pekosz, A. The $X s$ and $Y$ of immune responses to viral vaccines. Lancet Infect Dis 10, 338-349, doi:10.1016/s1473-3099(10)70049-9 PMID - 20417416 (2010).

$44 \quad$ Klein, S. L. \& Gearhart, P. J. Commentary for the 'VSI: Aging and sex in immunity'. Cell Immunol 348, 104037, doi:10.1016/j.cellimm.2019.104037 PMID - 31992440 (2020).

45 Potluri, T. et al. Age-associated changes in the impact of sex steroids on influenza vaccine responses in males and females. Npj Vaccines 4, 29, doi:10.1038/s41541-0190124-6 PMID - 31312529 (2019).

46 Bupp, M. R. G., Potluri, T., Fink, A. L. \& Klein, S. L. The Confluence of Sex Hormones and Aging on Immunity. Front Immunol 9, 1269, doi:10.3389/fimmu.2018.01269 PMID 29915601 (2018).

47 Wong, K. C., Luscombe, G. M. \& Hawke, C. Influenza infections in Australia 2009-2015: is there a combined effect of age and sex on susceptibility to virus subtypes? BMC Infectious Diseases 19, 42, doi:10.1186/s12879-019-3681-4 PMID - 30630435 (2019).

48 Wang, X.-L. et al. Age and Sex Differences in Rates of Influenza-Associated Hospitalizations in Hong Kong. Am J Epidemiol 182, 335-344, doi:10.1093/aje/kwv068 PMID - 26219977 (2015).

49 Kuo, H. et al. Sex-specific effects of age and body mass index on antibody responses to seasonal influenza vaccines in healthcare workers. Vaccine (2021).

50 Nauta, J. Statistics in Clinical Vaccine Trials - Adjusting for Imbalance in Pre-Vaccination State. 57-65, doi:10.1007/978-3-642-14691-6_5 (2010).

51 Weinberger, B., Herndler-Brandstetter, D., Schwanninger, A., Weiskopf, D. \& GrubeckLoebenstein, B. Biology of Immune Responses to Vaccines in Elderly Persons. Clin Infect Dis 46, 1078-1084, doi:10.1086/529197 PMID - 18444828 (2008).

52 Centers for Disease Control and Prevention. Influenza Historic Timeline, $<$ https://www.cdc.gov/flu/pandemic-resources/pandemic-timeline-1930-andbeyond.htm> (2019).

53 Bitzegeio, J., Majowicz, S., Matysiak-Klose, D., Sagebiel, D. \& Werber, D. Estimating agespecific vaccine effectiveness using data from a large measles outbreak in Berlin, Germany, 2014/15: evidence for waning immunity. Eurosurveillance 24, 1800529 (2019).

54 Crooke, S. N. et al. Durability of humoral immune responses to rubella following MMR vaccination. Vaccine 38, 8185-8193 (2020).

55 Savage, R. D. et al. A multisite study of pertussis vaccine effectiveness by time since last vaccine dose from three Canadian provinces: A Canadian Immunization Research Network study. Vaccine 39, 2772-2779 (2021).

56 Posuwan, N. et al. The success of a universal hepatitis B immunization program as part of Thailand's EPI after 22 years' implementation. Plos One 11, e0150499 (2016).

57 Miller, M. S. et al. Neutralizing Antibodies Against Previously Encountered Influenza Virus Strains Increase over Time: A Longitudinal Analysis. 
medRxiv preprint doi: https://doi.org/10.1101/2021.07.21.21260712; this version posted July 23, 2021. The copyright holder for this preprint (which was not certified by peer review) is the author/funder, who has granted medRxiv a license to display the preprint in perpetuity.

63858 Flanagan, K. L., Fink, A. L., Plebanski, M. \& Klein, S. L. Sex and Gender Differences in the 639 Outcomes of Vaccination over the Life Course. Annu Rev Cell Dev Bi 33, 577-599,

640

641

642

643

644

645

646

647

648

649

650

651

652

653

$654 \quad 64$

655

656

657

658

659

$660 \quad 66$

661

662

663

664

665

666

667

668

669

670

671

672

673

674

675 doi:10.1146/annurev-cellbio-100616-060718 PMID - 28992436 (2017).

59 Liu, M. et al. Antigenic patterns and evolution of the human influenza A (H1N1) virus. Scientific reports 5, 1-8 (2015).

60 Vijaykrishna, D. et al. The contrasting phylodynamics of human influenza B viruses. Elife 4, e05055 (2015).

61 Caini, S. et al. The epidemiological signature of influenza B virus and its B/Victoria and B/Yamagata lineages in the 21st century. Plos One 14, e0222381, doi:10.1371/journal.pone.0222381 PMID - 31513690 (2019).

62 World Health Organization. WHO recommendations on the composition of influenza virus vaccines, <https://www.who.int/influenza/vaccines/virus/recommendations/en/> (2021).

63 Auladell, M. et al. Recalling the Future: Immunological Memory Toward Unpredictable Influenza Viruses. Front Immunol 10, 1400, doi:10.3389/fimmu.2019.01400 PMID 31312199 (2019).

64 Hannoun, C. The evolving history of influenza viruses and influenza vaccines. Expert review of vaccines 12, 1085-1094 (2013).

65 Nuñez, I. A. et al. Impact of age and pre-existing influenza immune responses in humans receiving split inactivated influenza vaccine on the induction of the breadth of antibodies to influenza A strains. Plos One 12, e0185666, doi:10.1371/journal.pone.0185666 PMID - 29091724 (2017).

66 Khiabanian, H., Farrell, G. M., George, K. S. \& Rabadan, R. Differences in patient age distribution between influenza A subtypes. Plos One 4, e6832 (2009).

67 Gostic, K. M. et al. Childhood immune imprinting to influenza A shapes birth yearspecific risk during seasonal H1N1 and H3N2 epidemics. PLOS Pathogens 15, e1008109, doi:10.1371/journal.ppat.1008109 PMID - 31856206 (2019).

68 Dunning, A. J. et al. Correlates of Protection against Influenza in the Elderly: Results from an Influenza Vaccine Efficacy Trial. Clin Vaccine Immunol 23, 228-235, doi:10.1128/cvi.00604-15 PMID - 26762363 (2016).

69 Shapiro, J. R., Klein, S. L. \& Morgan, R. COVID-19: use intersectional analyses to close gaps in outcomes and vaccination. Nature 591, 202 (2021).

70 Greenberg, D. P. et al. Safety and immunogenicity of a quadrivalent inactivated influenza vaccine compared to licensed trivalent inactivated influenza vaccines in adults. Vaccine 31, 770-776 (2013).

71 Newson, R. B. Sensible parameters for univariate and multivariate splines. The Stata Journal 12, 479-504 (2012). 
medRxiv preprint doi: https://doi.org/10.1101/2021.07.21.21260712; this version posted July 23, 2021. The copyright holder for this preprint (which was not certified by peer review) is the author/funder, who has granted medRxiv a license to display the preprint in perpetuity.

All rights reserved. No reuse allowed without permission.

Shapiro et al. 27

$676 \quad$ Figure Legends

677 Figure 1. Study design

678 Study procedures and the three strains included in each seasonal HD-IIV3 are shown. Serum

679 from blood draws was used to evaluate pre- and post-vaccination strain-specific

680 hemagglutination antibody inhibition (HAI) titers, and frailty was assessed using the Frailty

681 Phenotype.

682

683

Figure 2. Relationship of age, frailty status, and BMI with post-vaccination hemagglutination antibody inhibition (HAI) titers outcomes

685 The relationship of age (in decades, Age/10), frailty status, and BMI (five-unit intervals, BMI/5)

686 with $\log _{2}$-transformed post-vaccination titers are shown as slopes for HAI titers against H1N1

687 (a), H3N2 (b) and influenza B (c). The relationships of these host factors with $\log _{10}$-transformed 688 fold-rise in titers (post-titer/pre-titer) are shown as slopes for H1N1 (d), H3N2 (e) and influenza

689 B (f). Their relationships with log odds of seroconversion are shown for H1N1 (g), H3N2 (h) and

690 influenza B (i). Estimates and 95\% confidence intervals were derived from multi-level mixed

691 effects models with random intercepts on the individual participant. Models controlled for

692 study year and pre-vaccination HAl titers, and either controlled for sex (whole population

693 estimates) or used interaction terms between sex and the host factor of interest to derive sex-

694 specific estimates.

695

696 Figure 3. Relationship of repeat annual vaccination with post-vaccination hemagglutination 
medRxiv preprint doi: https://doi.org/10.1101/2021.07.21.21260712; this version posted July 23, 2021. The copyright holder for this preprint (which was not certified by peer review) is the author/funder, who has granted medRxiv a license to display the preprint in perpetuity.

All rights reserved. No reuse allowed without permission.

Shapiro et al. 28

698 The relationship between increasing years of vaccination and $\log _{2}$-transformed post-vaccination

699 HAl titers are shown for each vaccine antigen (a-c), with slopes summarized (d). Similarly, the

700 relationship between increasing years of vaccination and the $\log _{10}$-transformed fold-rise in

701 titers are shown for H1N1, H3N2, and influenza B (e-g), with the slopes summarized (h). The

702 relationship between increasing years of vaccination and probability of seroconversion are

703 shown for antibody responses against $\mathrm{H} 1 \mathrm{~N} 1, \mathrm{H} 3 \mathrm{~N} 2$, and influenza B, respectively (i-k), with the

704 logs odds ratios summarized (I). All models controlled for study year, pre-vaccination titers, and

705 age at vaccination. Whole-population models controlled for sex, while sex-specific estimates

706 were derived from models including an interaction term between sex and years of participation

707 and are shown with 95\% confidence intervals. Asterisks indicate significant sex differences.

708

709

Figure 4. Relationship between pre-vaccination hemagglutination antibody inhibition (HAl)

titers and post-vaccination HAl titer outcomes

711 Relationships between $\log _{2}$-transformed pre-vaccination HAl titers and $\log _{2}$-transformed post-

712 vaccination titers are shown for responses to $H 1 N 1, H 3 N 2$, and influenza B, respectively (a-c),

713 with slopes summarized $(\mathbf{d})$. The relationships between pre-vaccination HAI titers and the $\log _{10^{-}}$

714 transformed fold-rise in titers are shown for each vaccine antigen (e-g), with the slopes

715 summarized $(\mathbf{h})$. The relationships between pre-vaccination HAl titers and the probability of

716 seroconversion are shown for $\mathrm{H} 1 \mathrm{~N} 1, \mathrm{H} 3 \mathrm{~N} 2$, and influenza $\mathrm{B}$, respectively (i-k), with the log odds

717 ratios summarized (I). All models controlled for study year. Overall estimates controlled for sex,

718 while sex-specific estimates were derived from models that included an interaction term

719 between sex and pre-vaccination titers and are shown with 95\% confidence intervals. 
medRxiv preprint doi: https://doi.org/10.1101/2021.07.21.21260712; this version posted July 23, 2021. The copyright holder for this preprint (which was not certified by peer review) is the author/funder, who has granted medRxiv a license to display the preprint in perpetuity.

Shapiro et al. 29

721 Figure 5. Relationship of age, frailty status, and BMI to pre-vaccination hemagglutination

722 antibody inhibition (HAI) titers

723 Estimates for the relationship of age in decades (Age/10), frailty status, and BMI (five-unit

724 intervals, $\mathrm{BMI} / 5$ ) to pre-vaccination $\mathrm{HAl}$ titers were derived from multilevel mixed-effects

725 models controlling for study year for H1N1 (a), H3N2 (b), and influenza B (c). Expanded age

726 models controlling for frailty and BMI are shown for responses to H1N1 (d), H3N2 (e), and

727 influenza B (f). Expanded models for responses to H1N1 (g), H3N2 (h), and influenza B (I) were

728 then amended to include cubic B-splines for age with knots at 5-year intervals. Models for the

729 whole study population adjusted for sex, while sex-specific estimates included an interaction

730 term allowing effects to differ by sex and are shown with $95 \%$ confidence intervals. Asterisks

731 indicate significant sex differences. 
734 Table 1. Summary of study population characteristics

\begin{tabular}{|c|c|c|c|}
\hline & All & Male & Female \\
\hline Person-seasons - n (\%) & 433 & $192(44.3)$ & $241(55.7)$ \\
\hline Individuals - n (\%) & 90 & $40(44.4)$ & $50(55.6)$ \\
\hline \multicolumn{4}{|l|}{ Yearly participation - n (\%) } \\
\hline 2014 & $45(50.0)$ & $19(47.5)$ & $26(52.0)$ \\
\hline 2015 & $68(75.6)$ & $28(70.0)$ & $40(80.0)$ \\
\hline 2016 & $68(75.6)$ & 31 (77.5) & $37(74.0)$ \\
\hline 2017 & 87 (96.7) & $38(95.0)$ & $49(98.0)$ \\
\hline 2018 & $88(97.8)$ & $40(100.0)$ & $48(96.0)$ \\
\hline 2019 & $77(85.6)$ & $36(90.0)$ & $41(82.0)$ \\
\hline \multicolumn{4}{|l|}{ Number of years participated } \\
\hline 4 & $40(44.4)$ & $18(45.0)$ & $22(44.0)$ \\
\hline 5 & $27(30.0)$ & $12(30.0)$ & $15(30.0)$ \\
\hline 6 & $23(25.6)$ & $10(25.0)$ & $13(26.0)$ \\
\hline Birth year - Median (p25-p75) & 1934 (1930 - 1938) & 1934 (1929 - 1938) & $1934(1930-1938)$ \\
\hline Range & $1916-1941$ & $1922-1941$ & $1916-1940$ \\
\hline \multicolumn{4}{|l|}{ Baseline characteristics $^{a}$} \\
\hline Age - Median (p25-p75) & $80(77-83)$ & $80(77-84)$ & $80(77-83)$ \\
\hline \multicolumn{4}{|l|}{ Frailty - n (\%) } \\
\hline Non-frail & $37(41.1)$ & $17(42.5)$ & $20(40.0)$ \\
\hline Pre-frail & $48(53.3)$ & $21(52.5)$ & $27(54.0)$ \\
\hline Frail & $5(5.6)$ & $2(5.0)$ & $3(6.0)$ \\
\hline BMI - Median (p25-p75) & $26.8(24.5-30.4)$ & $27.0(25.3-29.6)$ & $26.5(23.2-30.5)$ \\
\hline \multicolumn{4}{|l|}{ Change from baseline $^{b}$} \\
\hline \multicolumn{4}{|l|}{ Frailty - n (\%) } \\
\hline Improved & $11(12.2)$ & $8(20.0)$ & $3(6.0)$ \\
\hline No change & 44 (48.9) & $18(45.0)$ & $26(52.0)$ \\
\hline Worsened & 35 (38.9) & $14(35.0)$ & $21(42.0)$ \\
\hline \multicolumn{4}{|l|}{ BMI } \\
\hline Decreased & $39(43.3)$ & $19(47.5)$ & $20(40.0)$ \\
\hline No change $(+/-1)$ & $38(42.2)$ & $14(35.0)$ & $24(48.0)$ \\
\hline Increased & $13(14.4)$ & $7(17.5)$ & $6(12.0)$ \\
\hline
\end{tabular}

a Value for first year participated

${ }^{b}$ Difference between first and last year participated 
Table 2. Pre- and post-vaccination hemagglutination antibody inhibition (HAl) titer outcomes

\begin{tabular}{|c|c|c|c|c|}
\hline & All & Males & Females & Sex difference* \\
\hline Person-seasons - n (\%) & 433 & $192(44.3)$ & $241(55.7)$ & \\
\hline \multicolumn{5}{|l|}{ H1N1 } \\
\hline Post-vaccination - GMT (95\% Cl) & $192.3(174.6-211.9)$ & $185.9(161.5$ - 213.9) & $197.7(173.0-225.9)$ & 0.8922 \\
\hline Pre-vaccination SPR - n (\%) & $325(75.1)$ & $149(77.6)$ & $176(73.0)$ & 0.4116 \\
\hline Post-vaccination SPR - n (\%) & $415(95.8)$ & $184(95.8)$ & 231 (95.9) & 0.7837 \\
\hline Seroconversion rate $-\mathrm{n}(\%)$ & $134(30.9)$ & $47(24.5)$ & $87(36.1)$ & 0.1932 \\
\hline \multicolumn{5}{|l|}{ H3N2 } \\
\hline Pre-vaccination - GMT $(95 \% \mathrm{Cl})$ & $89.3(77.0-103.5)$ & $91.8(73.0-115.4)$ & $87.3(71.9-106.0)$ & 0.8246 \\
\hline Post-vaccination - GMT (95\% Cl) & $363.1(316.3-416.8)$ & $365.0(292.3-455.9)$ & $361.5(303.5-430.6)$ & 0.8793 \\
\hline Pre-vaccination SPR - n (\%) & $314(72.5)$ & $141(73.4)$ & $173(71.8)$ & 0.8855 \\
\hline \multicolumn{5}{|l|}{ B } \\
\hline Pre-vaccination - GMT $(95 \% \mathrm{Cl})$ & $262.8(235.3-293.4)$ & $236.3(204.8-272.6)$ & $286.0(243.1-336.4)$ & 0.2847 \\
\hline Post-vaccination - GMT (95\% Cl) & $571.1(520.2-627.1)$ & $508.5(445.8-580.1)$ & $626.5(549.7-714.0)$ & 0.1735 \\
\hline Pre-vaccination SPR - n (\%) & 424 (97.9) & $191(99.5)$ & $233(96.7)$ & 0.2887 \\
\hline Post-vaccination SPR - n (\%) & $433(100.0)$ & $192(100.0)$ & $241(100.0)$ & 0.2887 \\
\hline Fold-rise $(\log 10)$ - mean $(95 \% \mathrm{Cl})$ & $0.337(0.304-0.370)$ & $0.333(0.288-0.378)$ & $0.341(0.294-0.387)$ & 0.9482 \\
\hline Seroconversion rate - $\mathrm{n}(\%)$ & $105(24.2)$ & $47(24.5)$ & $58(24.1)$ & 0.8386 \\
\hline
\end{tabular}

* Sex difference p-values derived from multi-level linear (GMT) or logistic regressions (SPR and SCR). Fixed effects included a term for sex and controlled for study year. Random effects included a random intercept on the individual.

Abbreviations \& definitions: $\mathrm{Cl}$ : confidence interval; Fold-rise: post-vaccination titer divided by pre-vaccination titer, transformed on the log 10 scale; GMT: geometric mean titer; SPR: seroprotection rate, the proportion of individuals who achieved a titer $\geq 40$; Seroconversion rate: the proportion of individuals who achieved a fold-rise in titer $\geq 4$. 
Table 3. Sex-specific effects of age on pre-vaccination hemagglutination antibody inhibition (HAI) titers

\begin{tabular}{|c|c|c|c|c|c|c|c|c|c|c|c|c|}
\hline & \multicolumn{6}{|c|}{ Base Models $^{\mathrm{a}}$} & \multicolumn{6}{|c|}{ Expanded Models $^{b}$} \\
\hline & \multicolumn{2}{|c|}{ Male age effects } & \multicolumn{2}{|c|}{ Female age effects } & \multicolumn{2}{|c|}{ Sex difference $^{c}$} & \multicolumn{2}{|c|}{ Male age effects } & \multicolumn{2}{|c|}{ Female age effects } & \multicolumn{2}{|c|}{ Sex difference ${ }^{c}$} \\
\hline & Change & $p$-value & Change & p-value & Difference & $p$-value & Change & p-value & Change & p-value & Difference & p-value \\
\hline \multicolumn{13}{|l|}{ H1N1 } \\
\hline Linear & 0.047 & 0.164 & 0.034 & 0.286 & -0.014 & 0.674 & 0.049 & 0.152 & 0.035 & 0.267 & -0.014 & 0.676 \\
\hline \multicolumn{13}{|l|}{ Non-linear } \\
\hline $75-80$ & 0.379 & 0.300 & 0.146 & 0.650 & -0.023 & 0.963 & 0.383 & 0.301 & 0.134 & 0.685 & -0.010 & 0.984 \\
\hline $80-85$ & 0.133 & 0.564 & 0.233 & 0.251 & -0.256 & 0.465 & 0.131 & 0.574 & 0.243 & 0.238 & -0.259 & 0.462 \\
\hline $85-90$ & 0.205 & 0.397 & 0.109 & 0.589 & -0.156 & 0.657 & 0.220 & 0.377 & 0.113 & 0.593 & -0.147 & 0.678 \\
\hline $90-95$ & 0.421 & 0.188 & 0.066 & 0.830 & -0.253 & 0.547 & 0.430 & 0.186 & 0.071 & 0.817 & -0.254 & 0.553 \\
\hline 95 & & & & & -0.609 & 0.31 & & & & & -0.612 & 0.313 \\
\hline \multicolumn{13}{|l|}{ H3N2 } \\
\hline Linear & -0.067 & 0.133 & 0.065 & 0.103 & 0.131 & 0.014 & -0.075 & 0.097 & 0.062 & 0.121 & 0.137 & 0.010 \\
\hline \multicolumn{13}{|l|}{ Non-linear } \\
\hline $75-80$ & -1.725 & 0.015 & -0.156 & 0.801 & -1.898 & 0.029 & -1.776 & 0.012 & -0.297 & 0.637 & -1.833 & 0.036 \\
\hline $80-85$ & -0.139 & 0.711 & 0.653 & 0.039 & -0.328 & 0.469 & -0.102 & 0.786 & 0.670 & 0.037 & -0.355 & 0.435 \\
\hline $85-90$ & 0.023 & 0.953 & 0.114 & 0.716 & 0.463 & 0.326 & -0.048 & 0.904 & 0.149 & 0.651 & 0.417 & 0.379 \\
\hline $90-95$ & -0.496 & 0.39 & -0.415 & 0.430 & 0.553 & 0.351 & -0.591 & 0.307 & -0.421 & 0.431 & 0.614 & 0.308 \\
\hline 95 & & & & & 0.634 & 0.503 & & & & & 0.784 & 0.412 \\
\hline \multicolumn{13}{|l|}{ B } \\
\hline Linear & -0.098 & 0.005 & 0.009 & 0.762 & 0.108 & 0.007 & -0.078 & 0.023 & 0.033 & 0.275 & 0.111 & 0.005 \\
\hline \multicolumn{13}{|l|}{ Non-linear } \\
\hline $75-80$ & -0.315 & 0.516 & 0.965 & 0.023 & -1.051 & 0.087 & -0.189 & 0.693 & 1.203 & 0.004 & -1.048 & 0.080 \\
\hline $80-85$ & -0.106 & 0.695 & 0.161 & 0.486 & 0.229 & 0.511 & 0.038 & 0.886 & 0.219 & 0.330 & 0.344 & 0.298 \\
\hline $85-90$ & -0.291 & 0.306 & -0.534 & 0.019 & 0.496 & 0.165 & -0.181 & 0.515 & -0.111 & 0.633 & 0.525 & 0.123 \\
\hline $90-95$ & -1.799 & 0.000 & -0.434 & 0.248 & 0.253 & 0.572 & -1.649 & 0.000 & -0.233 & 0.526 & 0.595 & 0.168 \\
\hline 95 & & & & & 1.618 & 0.020 & & & & & 2.011 & 0.003 \\
\hline
\end{tabular}

Base models controlled for study year.

744 bexpanded models controlled for study year, frailty, and BMI.

$745{ }^{c}$ For linear models, the sex-difference is the age-sex interaction term. For non-linear models, the sex difference is at the beginning of each five-year interval.

746 Non-linear models include cubic B-splines with knots at 5-year age intervals from 75-95 years.

747 Statistically significant values are bolded. 
medRxiv preprint doi: https://doi.org/10.1101/2021.07.21.21260712; this version posted July 23, 2021. The copyright holder for this preprint (which was not certified by peer review) is the author/funder, who has granted medRxiv a license to display the preprint in perpetuity. All rights reserved. No reuse allowed without permission.

Shapiro et al. 33

748 Table 4. Goodness-of-fit comparison of pre-vaccination age models

\begin{tabular}{|l|cc|cc|}
\hline & \multicolumn{2}{|c|}{ Base models $^{\mathbf{a}}$} & \multicolumn{2}{c|}{ Expanded models $^{\mathbf{b}}$} \\
\hline Age-sex interaction & - & + & - & + \\
\hline H1N1 & & & & \\
$\quad$ Linear age & 1138.86 & 1140.69 & $\mathbf{1 1 3 1 . 0 5}$ & 1132.87 \\
$\quad$ Non-linear age & 1144.47 & 1151.51 & 1136.73 & 1143.72 \\
H3N2 & & & & \\
$\quad$ Linear age & 1693.38 & 1689.57 & 1666.94 & $\mathbf{1 6 6 2 . 8 3}$ \\
$\quad$ Non-linear age & 1694.58 & 1694.83 & 1667.28 & 1667.95 \\
B $\quad$ & & & & \\
$\quad$ Linear age & 1398.31 & 1393.17 & 1355.04 & 1349.28 \\
$\quad$ Non-linear age & 1388.09 & 1378.85 & 1344.94 & $\mathbf{1 3 3 7 . 2 6}$ \\
\hline
\end{tabular}

749 a Base models controlled for study year.

$750 \quad{ }^{b}$ Expanded models controlled for study year, frailty, and BMI.

751 The lowest AIC, corresponding to the best-fit model, is bolded for each virus.

752

753 


\section{Figure 1: Study design}

\begin{tabular}{|c|c|c|c|c|c|c|c|}
\hline & & 2014 & 2015 & 2016 & 2017 & 2018 & 2019 \\
\hline & & D0 $\mathrm{D} 28$ & D0 $\mathrm{D} 28$ & D0 $\quad$ D28 & D0 $\quad$ D28 & $\begin{array}{ll}\text { D0 } & \text { D28 }\end{array}$ & $\begin{array}{ll}\text { D0 } & \text { D28 }\end{array}$ \\
\hline & $\begin{array}{l}\text { Community-dwelling older adults } \\
\text { Age at vaccination: } 75+ \\
\text { Study participation: } 4+\text { years }\end{array}$ & 影 & 番 & 营 & 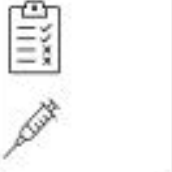 & 事 & 要 \\
\hline & A/California/7/2009 & & & & & & \\
\hline$\underset{3}{\mathrm{~T}}$ & A/Michigan/45/2015 & & & & & & \\
\hline & A/Brisbane/02/2018 & & & & & & \\
\hline & A/Texas/50/2012 & & & & & & \\
\hline & A/Switzerland/9715293/2013 & & & & & & \\
\hline$\sum_{m}^{N}$ & A/Hong Kong/4801/2014 & & & & & & \\
\hline & A/Singapore/INFIMH-16-0019/2016 & & & & & & \\
\hline & A/Kansas/14/2017 & & & & & & \\
\hline & B/Massachusetts/2/2012 (Yam) & & & & & & \\
\hline & B/Phuket/3073/2013 (Yam) & & & & & & \\
\hline$\underline{\simeq}$ & B/Brisbane/60/2008-like virus (Vic) & & & & & & \\
\hline & B/Maryland/15/2016 BX-69A (Vic) & & & & & & \\
\hline
\end{tabular}

Frailty \& vital signs assessment
High-dose trivalent inactivated influenza vaccine 
Fig 2. Relationship of age, frailty status, and BMI to post-vaccination HAI titers outcomes

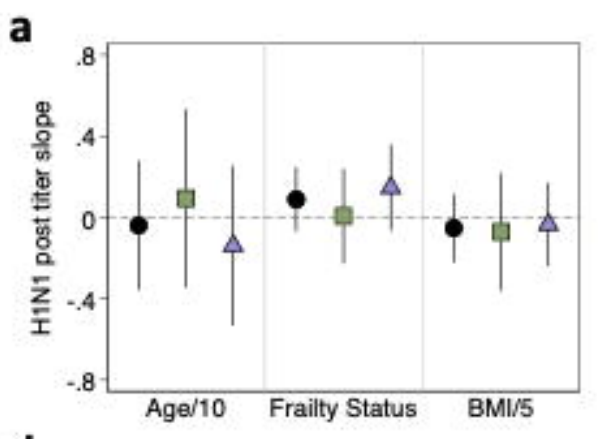

d

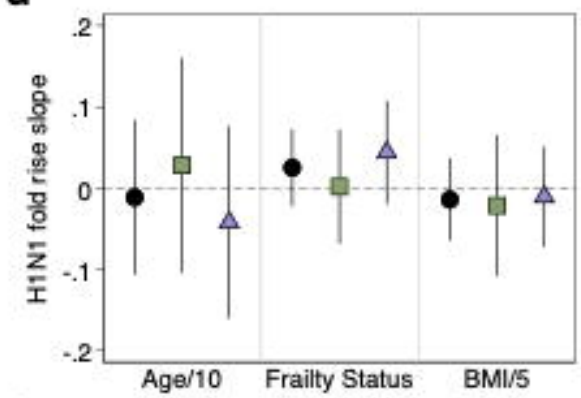

g

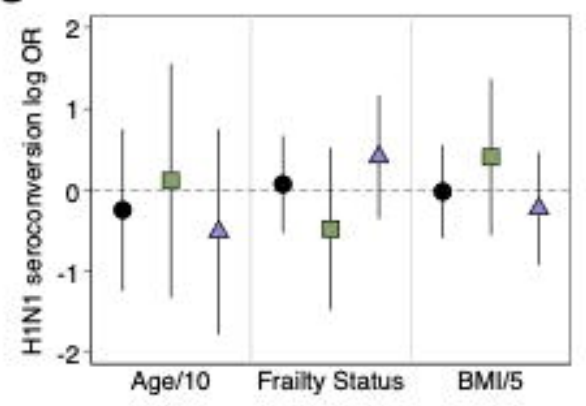

b

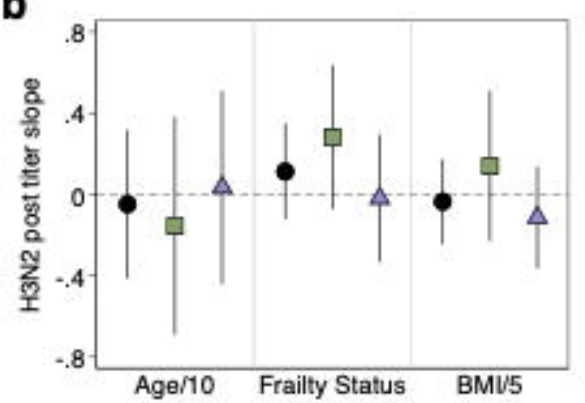

e

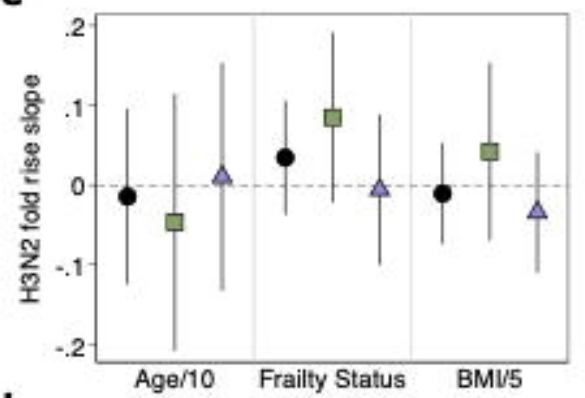

h

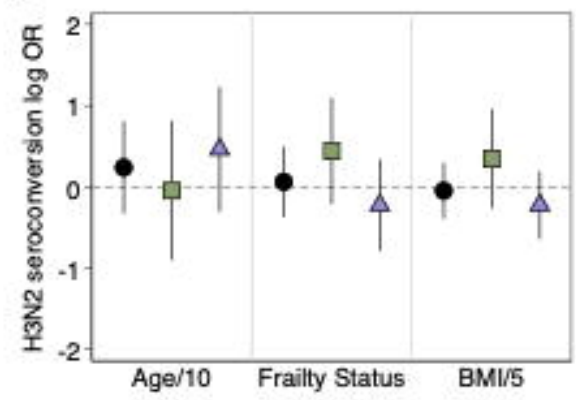

C

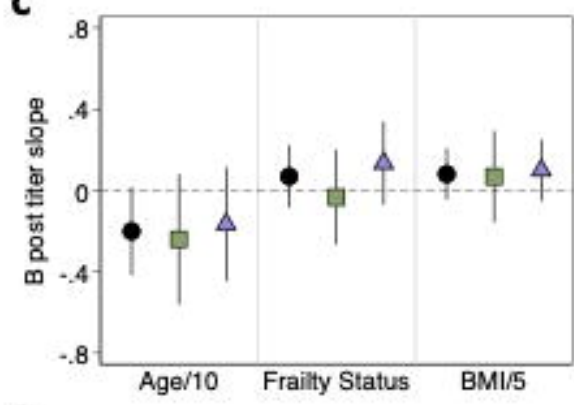

f

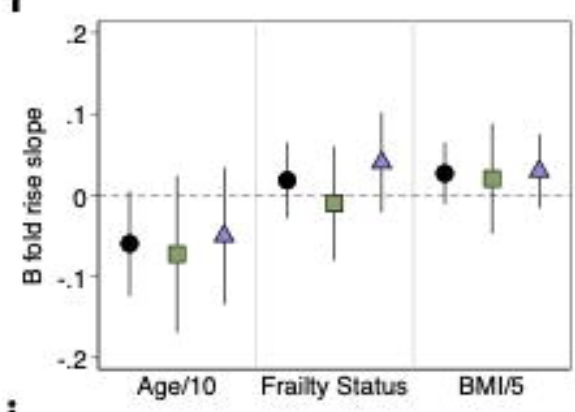

i

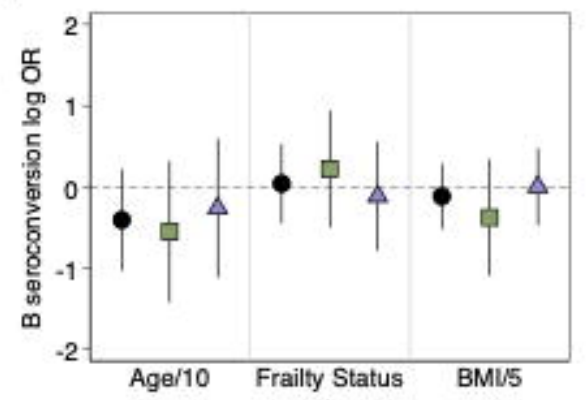




\section{Fig 3: Relationship of repeat annual vaccination to post-vaccination}

HAl titer outcomes

a

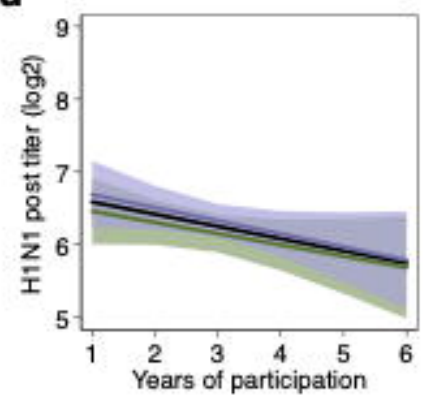

e
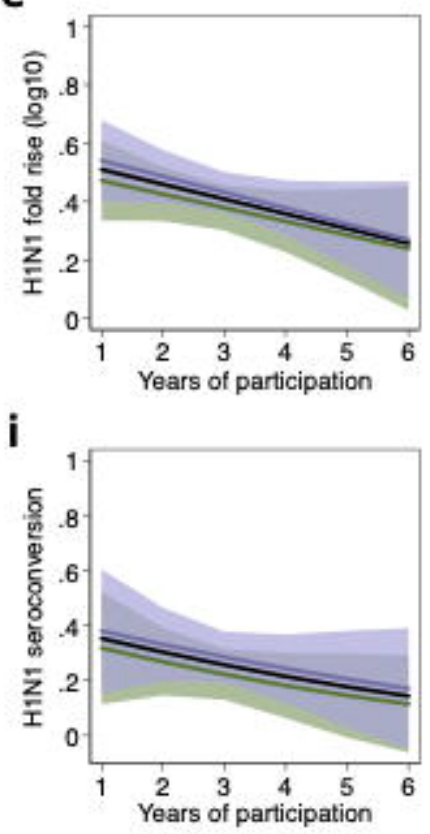

b

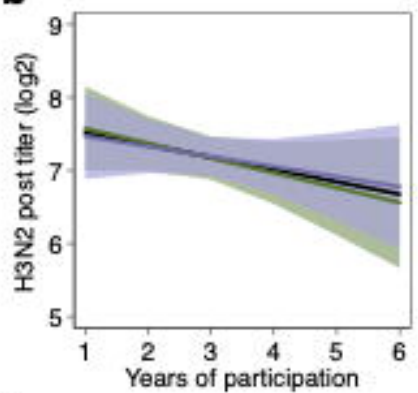

f

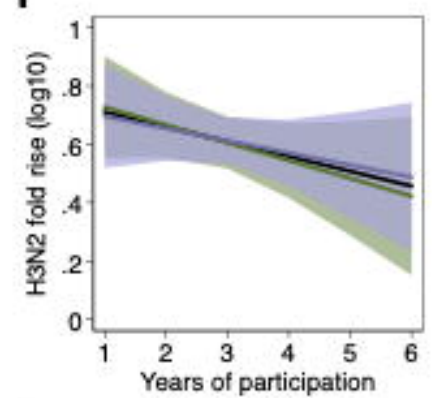

j

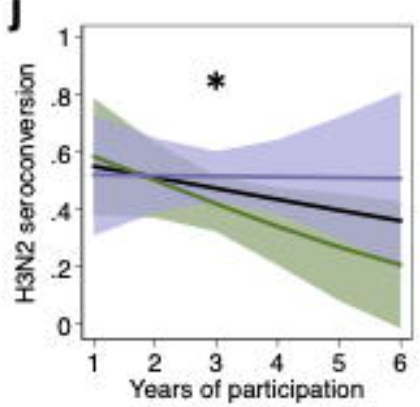

C

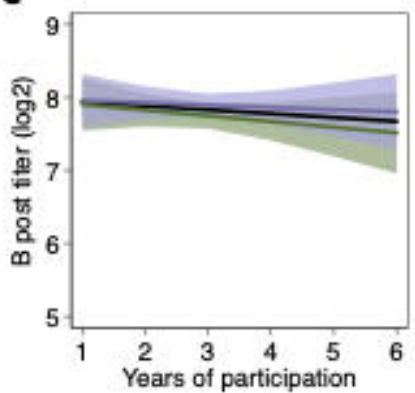

g

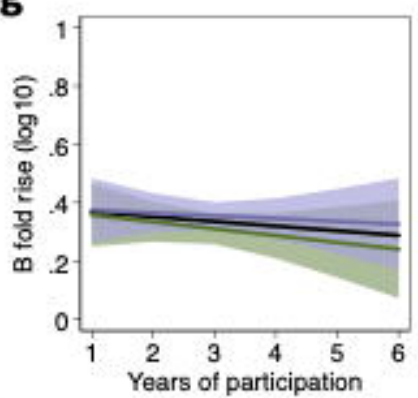

k

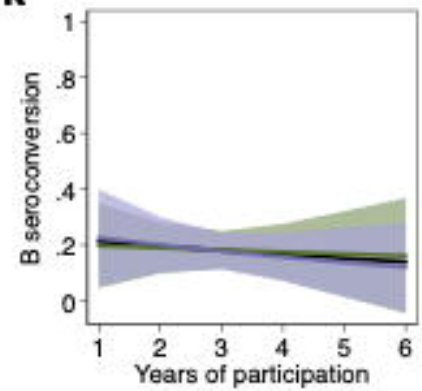

d

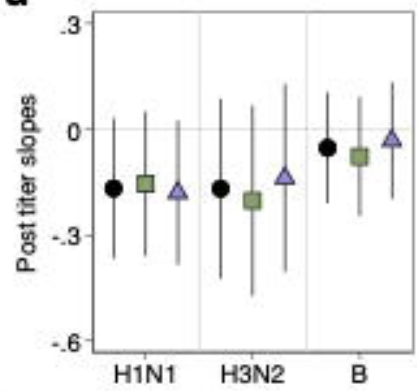

h

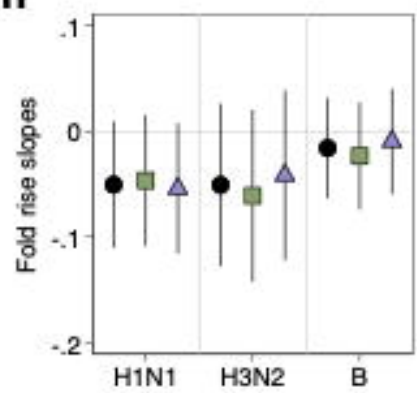

I

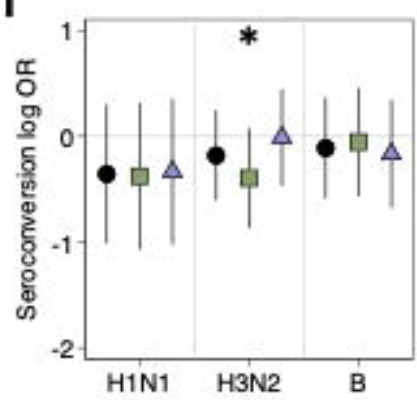


Fig 4. Relationship between pre-vaccination HAl titers and postvaccination HAl titer outcomes
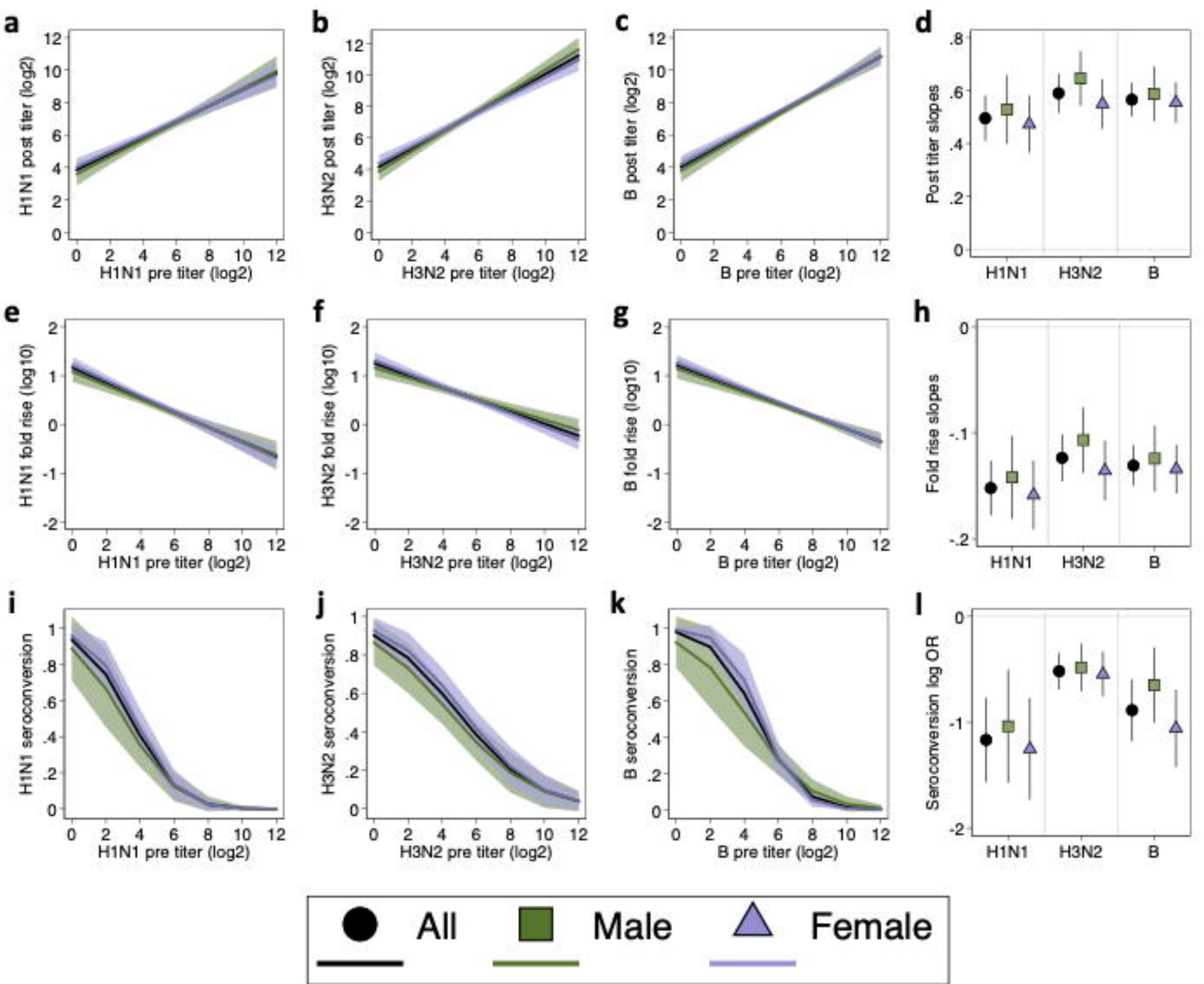
Fig 5. Relationship of age, frailty status, and BMI to pre-vaccination HAl titers

a

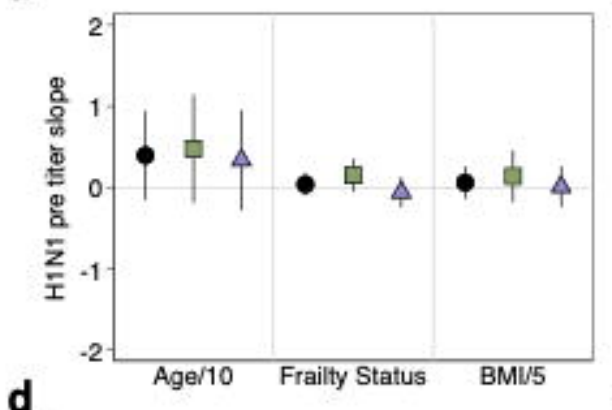

d

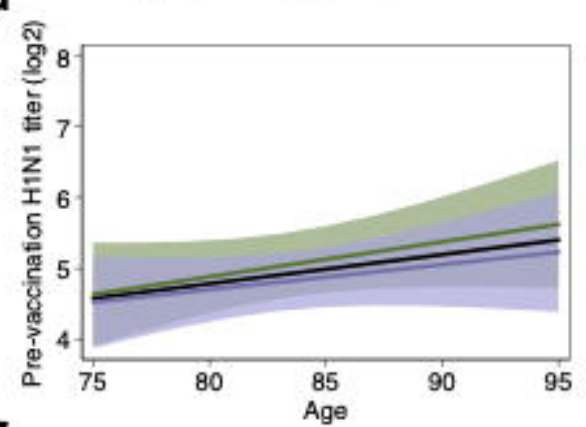

g

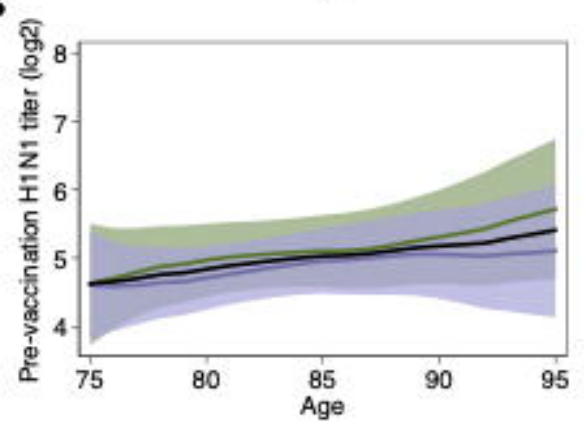

b

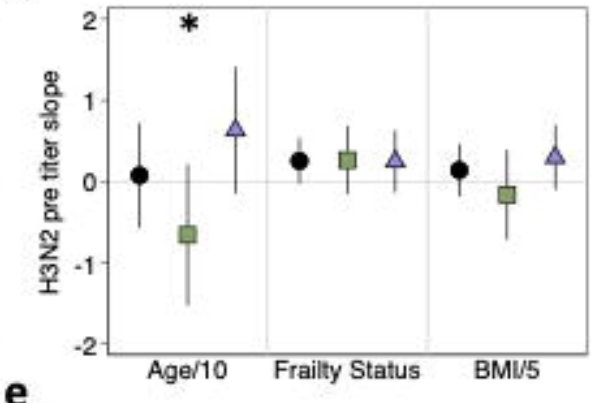

e

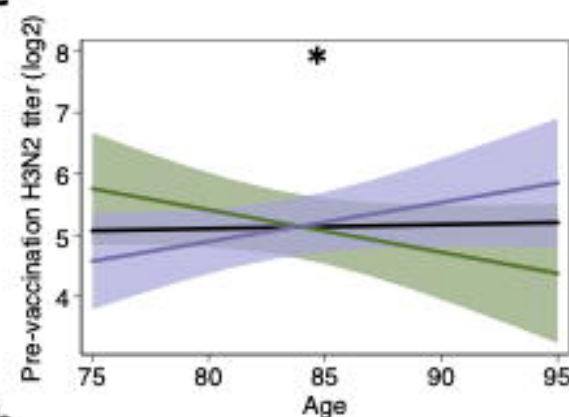

h

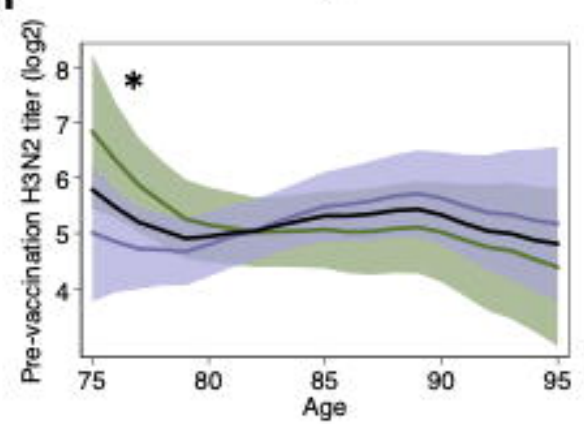

C
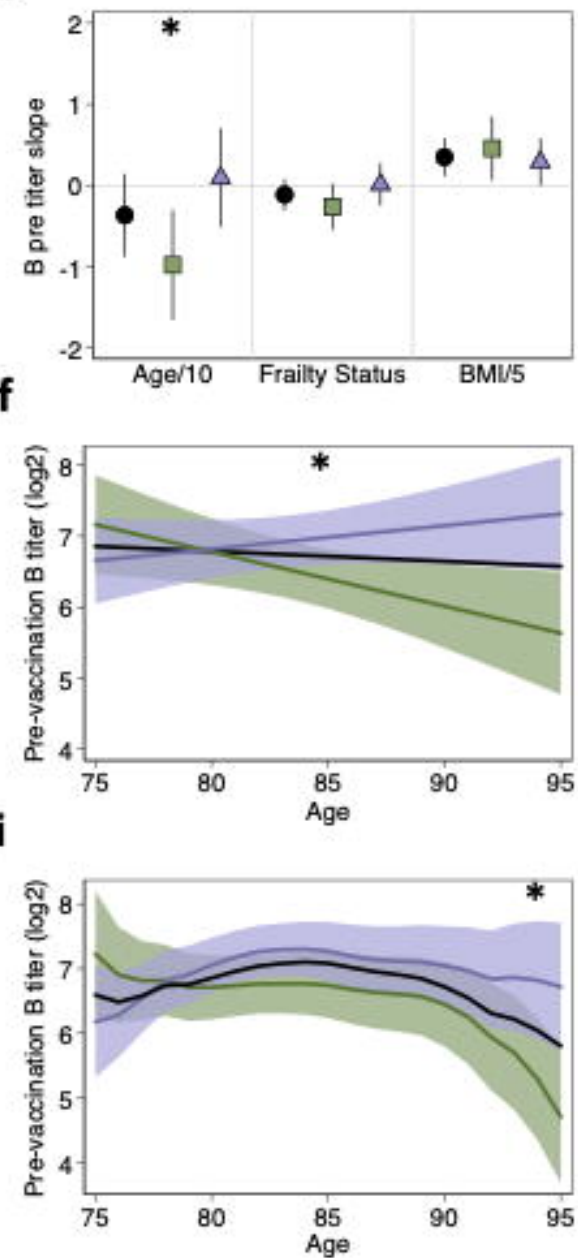

\section{All $\square$ Male $\triangle$ Female}

